WSRC-TR-2003-00030

Keywords: Filtration

Rotary Filter

Cross-Flow

Shielded Cells

\title{
Testing of the SpinTek Rotary Microfilter Using Actual Waste
}

By

D. T. Herman

M. R. Poirier

D. T. Hobbs

S. D. Fink 
This document was prepared in conjunction with work accomplished under Contract No. DE-AC09-96SR18500 with the U. S. Department of Energy.

\section{DISCLAIMER}

This report was prepared as an account of work sponsored by an agency of the United States Government. Neither the United States Government nor any agency thereof, nor any of their employees, makes any warranty, express or implied, or assumes any legal liability or responsibility for the accuracy, completeness, or usefulness of any information, apparatus, product or process disclosed, or represents that its use would not infringe privately owned rights. Reference herein to any specific commercial product, process or service by trade name, trademark, manufacturer, or otherwise does not necessarily constitute or imply its endorsement, recommendation, or favoring by the United States Government or any agency thereof. The views and opinions of authors expressed herein do not necessarily state or reflect those of the United States Government or any agency thereof.

This report has been reproduced directly from the best available copy.

Available for sale to the public, in paper, from: U.S. Department of Commerce, National Technical Information Service, 5285 Port Royal Road, Springfield, VA 22161, phone: (800) 553-6847, fax: (703) 605-6900

email: orders@ntis.fedworld.gov

online ordering: http://www.ntis.gov/help/index.asp

Available electronically at http://www.osti.gov/bridge

Available for a processing fee to U.S. Department of Energy and its contractors, in paper, from: U.S. Department of Energy, Office of Scientific and Technical Information, P.O. Box 62, Oak Ridge, TN 37831-0062,

phone: (865)576-8401,

fax: (865)576-5728

email: $\underline{\text { reports@ adonis.osti.gov }}$ 
WSRC-TR-2003-00030, Rev. 0

Page 3 of 33

February 2003

\section{THIS PAGE INTENTIONALLY LEFT BLANK}




\section{TABLE OF CONTENTS}

Summary 5

1.0 Introduction

2.0 Experimental $\quad 6$

2.2 Testing Description 7

2.2.1 Feed Preparation_

3.0 Results 11

3.1 Simulant 11

3.2 Testing With Actual Waste

3.2.1 0.1-Micron Disk with MST $\quad 16$

3.2.2 0.1-Micron Disk with Permanganate_ 21

3.2.3 0.5-Micron Disk with MST and Permanganate__ 26

4.0 Conclusions__ 29

5.0 Path Forward/Recommendations__

6.0 Quality Assurance__ 31

\begin{tabular}{lll} 
7.0 Acknowledgements & 31 \\
\hline
\end{tabular}

8.0 References $\quad 32$ 


\section{Summary}

We conducted filtration tests using a SpinTek Model II-1 rotary microfilter using both simulated and actual waste. The actual waste feed for the tests consisted of Savannah River Site (SRS) high-level waste supernate from Tank 37H, SRS high-level waste sludge from Tank 51H, strontium nitrate, sodium permanganate and monosodium titanate (MST). One slurry contained MST and sludge to achieve calculated insoluble solid concentrations of approximately $0.09,1.29$, and $4.5 \mathrm{wt} \%$. A second slurry contained sufficient sodium permanganate to achieve calculated insoluble solids concentrations of 0.23 , 3.28 and $11.7 \mathrm{wt} \%$. Testing used a filter disk with nominal pore size of either 0.1-micron or 0.5-micron.

The major conclusions from this work follow.

Data with simulant and MST agreed well with previous testing of the rotary microfilter using simulant showing a 2 to 6 times increase in filtration rate when using a 0.1 - or 0.5 -micron rotary filter in place of a 0.5 -micron cross-flow filter.

Results for actual-waste testing with MST and a 0.1-micron rotary filter showed 0 to $100 \%$ improvement in filter flux compared to prior tests using a 0.5 -micron cross-flow filter. Filtration rates using permanganate showed little improvement in filtration rate using the 0.1 -micron rotary filter as compared to the 0.5-micron Mott cross-flow filter. Analysis of the data as a function of time and post-test investigation suggests the 0.1-micron filter disk deteriorated over the course of the experiments. We believe the flow path created by the permeate carrier became successively constricted during the experiments causing a continual decline in performance. Hence, these experiments resulted in a low bias for the performance of the equipment.

We modified the design of the permeate carrier for the 0.5 -micron rotary filter. Testing with the 0.5 -micron rotary filter gave an increase in filtration rate of 6 to 10 times over the 0.5 -micron cross-flow filter for feed slurries treated with both MST and sodium permanganate. A significantly higher flux rate occurred for the 0.5-micron rotary filter versus the 0.1-micron rotary filter.

MST treatment followed by rotary filtration resulted in a strontium decontamination factor (DF) of 3 to 5 , but a strontium-90 activity above the design-specification value of $111,000 \mathrm{dpm} / \mathrm{mL}$. We identified several potential contributors for the failure to meet the design specification for strontium-90; including lack of equilibration, filter breakthrough, MST batch variability, MST particle attrition and sludge attrition. We believe the most likely contributor to the failure to meet the design specification for Sr removal involved sludge attrition releasing additional strontium.

We recommend additional studies related to the potential for sheared sludge to release strontium (and actinides) after treatment with MST. Should later testing confirm this phenomenon, design modifications may prove necessary to mitigate the processing risk.

For the treatment with MST, we measured a plutonium DF of 3 to 6 even though the initial plutonium concentration met the design specification. The DF for uranium equaled 0.7 to 2.0. The analysis for neptunium concentration in the feed showed a DF of 4 to 8 even with the initial concentration less than the design specification.

Permanganate treatment produced a strontium DF of greater than 40 with the strontium concentration after treatment in all samples meeting the design specification value. As above, a DF of 2 to 4 for plutonium content in the feed occurred even though the initial concentration met the design specification. The DF for uranium equaled 1.2 to 1.4. Analysis indicated a DF of 4 to 7 for neptunium even with the initial in the feed concentration less than the design specification.

We experienced pumping problems while testing with the permanganate solution. We did not encounter mechanical processing problems, however, while testing the feed solutions with MST. 


\subsection{Introduction}

The Department of Energy selected caustic-side solvent extraction (CSSX) as the preferred cesium-removal technology for SRS high-level waste. In the pretreatment step of the CSSX flowsheet, the incoming salt solution, which contains entrained sludge, is contacted with MST to adsorb strontium and selected actinides. An alternative approach replaces MST with the addition of sodium permanganate, strontium nitrate, and hydrogen peroxide. The pretreatment operation then filters the resulting slurry to remove the sludge and MST or manganese oxide and strontium carbonate solids. The filtrate receives further treatment in the solvent extraction system. Testing, with simulated waste using cross-flow filtration, performed by SRTC and the University of South Carolina showed relatively low filtration fluxes of $0.03-0.08$ $\mathrm{gpm} / \mathrm{ft}^{2}{ }^{2,2,3,4,5,6}$ Additional testing conducted with actual waste showed similar filtration rates. ${ }^{7,8}$

SRTC personnel coordinated tests using a SpinTek rotary microfilter at the vendor location in FY01. These tests demonstrated a significant improvement -2.5 to 6 times increase - in performance relative to the conventional cross-flow filter units. ${ }^{9}$ Therefore, program management requested SRTC personnel to test the SpinTek rotary micro-filter with actual high-level waste samples. ${ }^{10}$

We conducted filtration tests using a SpinTek model II-1 rotary microfilter located in the SRTC shielded cells. We modified the filter system to facilitate radioactive service in the cell. Testing used both simulated and actual waste. The simulated slurry contained a $5.6 \mathrm{M}$ sodium average salt solution, simulated Tank 8F sludge and MST. The actual-waste feed for the tests consisted of SRS high-level waste supernate from Tank $37 \mathrm{H}$, SRS high-level waste sludge from Tank $51 \mathrm{H}$, strontium nitrate, sodium permanganate and MST. The tests used a composite supernate containing 5.6 M sodium. We prepared two slurries for the testing. The first slurry contained MST and sludge to achieve calculated insoluble solid concentrations of approximately $0.09,1.29$, and $4.5 \mathrm{wt} \%$. The second slurry contained sufficient sodium permanganate and strontium nitrate to achieve calculated insoluble solids concentrations of $0.23,3.28$, and 11.7 wt $\%$.

Rotary microfilter testing used a filter disk with nominal pore size of either 0.1-micron or 0.5-micron. The custom-made disks used sintered metal sheets from Mott Corporation as the filter media. The disks differed slightly in design of the permeate carrier, which facilitates flow of the product liquid. We measured filter flux and filter decontamination factor. For determining the decontamination factor, we collected samples of filtrate and feed during each test and analyzed the samples to evaluate solids and radionuclide removal.

\subsection{Experimental}

\subsection{System Description ${ }^{11,12}$}

The SpinTek ST-II is a compact filtration system that uses membrane filters mounted on rotating disks. The vendor states that the equipment can produce high filtrate flow rates with stable performance even when operating on slurries with high solids content. The vendor conducted tests for Los Alamos National Laboratory (LANL) with $10.5-42$ wt $\%$ titanium dioxide slurries. ${ }^{12}$ The flux advantage of the rotary microfilter compared to other membrane processes results from the high shear and centrifugal force acting on the boundary layer next to the membrane. This shear greatly reduces fouling of the membrane surface and increases fluid flow through the membrane. Pressure is decoupled from the feed flow rate, allowing more control over the driving force pressure and independent control of the shear applied to the filter cake. This feature allows the direct application of shear force with a magnitude significantly greater than that available in conventional membrane systems. The membranes rotate at a tip speed of $60 \mathrm{ft} / \mathrm{s}$, which effectively cleans and sweeps solids from the membrane surface with a stable filtrate throughput. For comparison, previous cross-flow filter testing used axial velocities ranging from 3 to $25 \mathrm{ft} / \mathrm{s}^{1-4,7-8}$ The SpinTek rotary filter unit uses 11-inch diameter disks and typically operates with a rotational speed of $1170 \mathrm{rpm}$. 
The SpinTek high shear rotary filter uses from 1 to 25 disks covered with filter sheet membranes. The disks are physically mounted and are hydraulically connected to a common hollow rotating shaft. The entire stack of membrane disks is enclosed within a vessel. The feed fluid enters the vessel and flows across the membrane surface, where permeate flows through the membrane and exits through the hollow shaft. The concentrated slurry is pumped from the chamber. Stationary surfaces, or turbulence promoters, oppose the rotating membrane disks, generating large fluid shear rates across the membrane surface. Volumetric hold up is approximately 0.9 gallons for a single disk unit, and up to 4 gallons for a 25 disk unit. Personnel may find this value useful in determining maximum loading during maintenance periods. Figure 1 illustrates the flow paths during filtration.

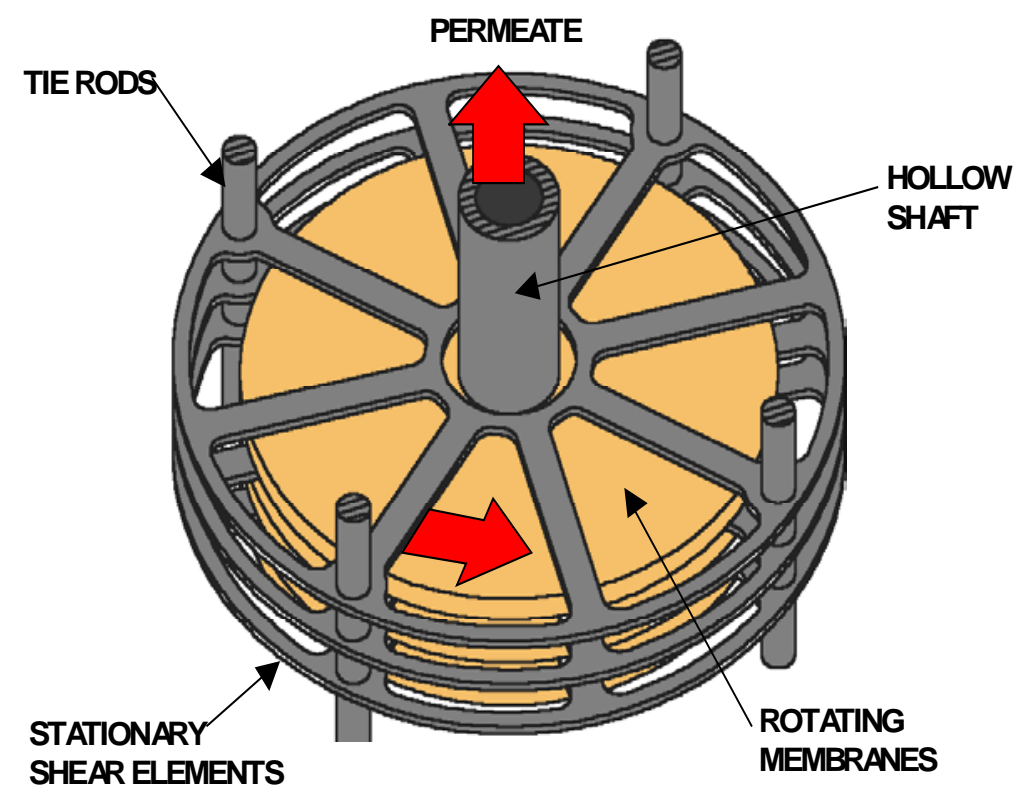

Figure 1. Illustration of SpinTek Rotary Filter with Three Filter Disks

The unit typically operates in a semi-batch mode with feed recirculated through the system and concentrated filtrate withdrawn. Eventually, the batch concentrates to a target insoluble solids level and the concentrated material is replaced with a new batch of feed.

We purchased the SpinTek ST-II for this testing as an off-the-shelf item and performed modifications for radioactive service. We modified the electrical, plumbing, and instrumentation systems. Modifications included the addition of calibrated manual pressure gauges for data collection as well as to aid in resolving potential system upsets. As testing started, we discovered the need to modify the prototype filter disk. To assure continued operation in the shielded-cells environment, we developed specialty tools and tested them before remote installation. These tools addressed both routine operation and remote disassembly of the equipment. The reader may consult the operating procedure for additional information on these tools. ${ }^{13}$

\subsection{Testing Description}

The system used for this testing contained a single filter disk with a filter membrane on each side. A positive displacement pump supplied feed. We piped the filtrate line to a graduated sight glass to allow for filtrate timings and to monitor filtrate flow. From the sight glass, the filtrate flowed back into the feed tank. By recycling the filtrate, we reduced the volume of feed sample required for testing. SpinTek defines the 
transmembrane pressure as the pressure at the filter disk. They consider the pressure downstream of the filter to be atmospheric. Therefore, the transmembrane pressure essentially equals the feed pressure. To be consistent with previous testing with SpinTek units, we use this definition of the transmembrane pressure throughout the report. Reporting the transmembrane pressure in this manner is conservatively high, as the actual pressure across the filter disk would be slightly lower.

Testing used both simulated and actual waste. Simulant testing occurred in the SRTC shielded cells mockup area. As modifications for radioactive testing finished, we operated the system using a $5.6 \mathrm{M}$ sodium simulant containing simulated sludge and MST. The first test used a slurry containing $0.09 \mathrm{wt} \%$ insoluble sludge solids $(0.6 \mathrm{~g} / \mathrm{L})$ and MST $(0.55 \mathrm{~g} / \mathrm{L})$. For the second test we increased both the MST and simulated sludge, maintaining a constant ratio of the sludge to MST solids, to obtain slurry with 1.29 wt \% total insoluble solids. We performed tests using both a 0.1 - and 0.5 -micron rotary filter. Personnel recorded filtration rates and compared to previous testing using a 0.5 -micron cross-flow filter ${ }^{8}$ and data from vendor testing in 2001. ${ }^{9}$ After testing, we cleaned the filter unit by feeding a $0.5 \mathrm{M}$ oxalic acid solution and running the filter for approximately one hour. To rinse and buffer the system, we drained the acid solution and ran a $0.01 \mathrm{M}$ sodium hydroxide solution.

Personnel installed the equipment in the shielded cells and tested it with actual waste consisting of Tank 37H supernate with Tank 51H sludge particles. Personnel split the prepared feed - see next section for details - into two portions for testing. The experiments used slurries treated with either MST or permanganate to reduce the amount of soluble actinides and strontium in the feed solution. The experimental design examined the performance of both 0.1 - and 0.5-micron filter disks with slurries of three nominal concentrations. Table 1 shows the sequence of experiments. During operation, technicians collected samples of the filtrate for analysis. Between experiments, we flushed the filter and pumping system with 6 liters of water for a minimum of one-half hour.

Table 1. Sequence of Experiments with Actual Waste

\begin{tabular}{|l|l|}
\hline \multicolumn{1}{|c|}{ Filter Media } & \multicolumn{1}{|c|}{ Feed Slurry $^{*}$} \\
\hline Nominal 0.1-micron pore-size rotary disk & (1) $0.09 \mathrm{wt} \% \mathrm{MST} / \mathrm{sludge}$ \\
& $\begin{array}{l}\text { (2) } 1.29 \mathrm{wt} \% \mathrm{MST} / \mathrm{sludge} \\
\text { (3) } 4.5 \mathrm{wt} \% \mathrm{MST} / \mathrm{sludge}\end{array}$ \\
& $\begin{array}{l}\text { (4) } 0.23 \mathrm{wt} \% \text { Permanganate/sludge } \\
\text { (5) } 3.28 \mathrm{wt} \% \text { Permanganate/sludge } \\
\text { Nominal 0.5-micron pore-size rotary disk }\end{array}$ \\
(6) $11.7 \mathrm{wt} \%$ Permanganate/sludge \\
\end{tabular}

*Concentrations shown represent calculated values of total solids content as prepared. For the permanganate treated material, calculated values assume complete conversion of the permanganate to $\mathrm{MnO}_{2}$ and the strontium nitrate to strontium carbonate.

\subsubsection{Feed Preparation}

We obtained samples of SRS high-level-waste supernate from Tank $37 \mathrm{H}^{14}$ The Analytical Development Section analyzed a sample for elemental components using Inductively Coupled Plasma Emission Spectroscopy and for density. Table 2 contains the results of these analyses. Prior to filter testing, we diluted the Tank $37 \mathrm{H}$ supernate from $15 \mathrm{M}$ to $5.6 \mathrm{M}$ sodium using $1.6 \mathrm{M} \mathrm{NaOH}$. 
WSRC-TR-2003-00030, Rev. 0

Page 9 of 33

February 2003

Table 2. Tank 37H Supernate Analysis ${ }^{14}$ Prior to Dilution

\begin{tabular}{|c|c|}
\hline Species & $\begin{array}{c}\text { Tank 37H } \\
\text { Supernate } \mathbf{g} / \mathbf{L}\end{array}$ \\
\hline $\mathrm{Al}$ & 26.36 \\
\hline $\mathrm{B}$ & 0.211 \\
\hline $\mathrm{Ba}$ & 0.009 \\
\hline $\mathrm{Ca}$ & 0.109 \\
\hline $\mathrm{Cd}$ & 0.009 \\
\hline $\mathrm{Cr}$ & 0.328 \\
\hline $\mathrm{Cu}$ & 0.005 \\
\hline $\mathrm{Fe}$ & 0.046 \\
\hline $\mathrm{Mg}$ & 0.004 \\
\hline $\mathrm{Mo}$ & 0.331 \\
\hline $\mathrm{Na}$ & 345.0 \\
\hline $\mathrm{P}$ & 1.25 \\
\hline $\mathrm{Sn}$ & 0.035 \\
\hline $\mathrm{Sr}$ & 0.0013 \\
\hline $\mathrm{U}$ & 0.0017 \\
\hline $\mathrm{Zn}$ & 0.021 \\
\hline
\end{tabular}

We also obtained an existing SRS high-level-waste sludge sample from Tank $51 \mathrm{H}$. Table 3 shows prior elemental analyses of a sample after digestion with aqua regia. 7,15

Table 3. Sludge Analysis ${ }^{7,15}$

\begin{tabular}{|c|c|}
\hline Species & Tank 51H Dried Sludge (wt \%) \\
\hline $\mathrm{Al}$ & 5.6 \\
\hline $\mathrm{Ca}$ & 2.2 \\
\hline $\mathrm{Cr}$ & 0.16 \\
\hline $\mathrm{Cu}$ & 0.024 \\
\hline $\mathrm{Fe}$ & 22.1 \\
\hline $\mathrm{Hg}$ & 0.14 \\
\hline $\mathrm{Mg}$ & 1.1 \\
\hline $\mathrm{Mn}$ & 2.3 \\
\hline $\mathrm{Na}$ & 14.4 \\
\hline $\mathrm{Mi}$ & 0.27 \\
\hline $\mathrm{P}$ & 0.48 \\
\hline $\mathrm{Si}$ & 0.57 \\
\hline $\mathrm{Ti}$ & 0.013 \\
\hline $\mathrm{U}$ & 3.1 \\
\hline
\end{tabular}

Personnel combined the $5.6 \mathrm{M} \mathrm{Na}^{+}$Tank $37 \mathrm{H}$ supernate and the Tank $51 \mathrm{H}$ sludge solids and sampled the slurry for analyses.

Personnel filtered the samples with a 0.45 -micron syringe filter and treated them with an equal volume of nitric acid and $0.5 \mathrm{~g}$ of ammonium molybdophosphate (AMP) to produce a solution of $\sim 0.5 \mathrm{M}$ nitric acid. The AMP adsorbed cesium, without removing plutonium or strontium, ${ }^{16}$ allowing less dilution of the sample before removal from the Shielded Cells. Technicians filtered the treated aliquot using a 0.45micron syringe filter to remove the AMP, and then submitted for analysis. We collected samples over time to ensure that the solids and supernate equilibrated prior to start of the experiments. Table 4 shows the actinide and strontium content of the composite supernate. We determined plutonium concentration by PuTTA and alpha counting, uranium and neptunium by ICP-MS, and the strontium by beta counting. 
WSRC-TR-2003-00030, Rev. 0

Page 10 of 33

February 2003

Table 4. Feed Analysis

\begin{tabular}{|c|c|c|c|c|}
\hline $\begin{array}{c}\text { Time } \\
\text { (days) }\end{array}$ & $\begin{array}{c}\mathbf{P u} \\
\mathbf{d p m} / \mathbf{m L}\end{array}$ & $\begin{array}{c}\mathbf{U} \\
\boldsymbol{\mathbf { g }} / \mathbf{L}\end{array}$ & $\begin{array}{c}\mathbf{N p} \\
\mathbf{d p m} / \mathbf{m L}\end{array}$ & $\begin{array}{c}\mathbf{9} \mathbf{S r} \\
\mathbf{d p m} / \mathbf{m L}\end{array}$ \\
\hline 14 & 5018 & 1511 & 13.5 & 501,000 \\
\hline & 5493 & 2850 & 13.2 & 509,000 \\
\hline 28 & 5099 & N/A & N/A & 752,000 \\
\hline & 5879 & N/A & N/A & 607,000 \\
\hline 35 & 7257 & 1930 & 18.4 & 456,000 \\
\hline & 4923 & 3660 & $<14.6$ & 356,000 \\
\hline
\end{tabular}

Personnel also collected an initial supernate sample, an initial slurry sample, and a 7-day filtrate sample. However, the treatment of these samples with AMP resin failed - due to incomplete acidification - yielding inconsistencies in the strontium and actinide data. We have omitted that data. The data from 14, 28, and 35 days after sludge addition show the soluble plutonium and strontium concentrations in the slurry reached equilibrium.

The strontium variance is approximately $30 \%$, the plutonium variance is approximately $15 \%$, the neptunium variance is approximately $16 \%$ and the uranium variance is approximately $40 \%$. These variances are higher than variances seen by other researchers conducting similar experiments. ${ }^{17}$ The large variations may result from slow equilibration of the sludge in the supernate. The amount of these materials in the sludge significantly exceeded the amount measured in the supernate.

After equilibration, we treated the first slurry with MST and the second using the permanganate treatment recipe. ${ }^{18}$ Table 5 shows the target insoluble solids concentration planned for each test.

Table 5. Target Insoluble Solids Concentration for Actual Waste Filter Tests

\begin{tabular}{|c|c|c|c|c|c|c|}
\hline & & $\begin{array}{l}\text { Sludge/MST } \\
\text { (total addition) }\end{array}$ & & & $\begin{array}{c}\mathrm{NaMnO}_{4} \\
\text { (total addition) }\end{array}$ & \\
\hline & Target & $\begin{array}{l}\text { Actual Added } \\
\text { to Feed }\end{array}$ & $\begin{array}{c}\text { Measured } \\
\text { wt \% } \\
\text { Insoluble } \\
\text { Solids }\end{array}$ & Target & $\begin{array}{l}\text { Actual Added } \\
\text { to Feed }\end{array}$ & $\begin{array}{l}\text { Measured } \\
\text { wt \% } \\
\text { Insoluble } \\
\text { Solids }\end{array}$ \\
\hline Test 1 & $\begin{array}{c}0.6 \mathrm{~g} / \mathrm{L} \text { sludge } \\
(0.09 \mathrm{wt} \%) \\
0.55 \mathrm{~g} / \mathrm{L} \mathrm{MST}\end{array}$ & $\begin{array}{l}0.6 \mathrm{~g} / \mathrm{L} \text { sludge } \\
0.55 \mathrm{~g} / \mathrm{L} \text { MST }\end{array}$ & 0.034 & $\begin{array}{c}0.60 \mathrm{~g} / \mathrm{L} \text { sludge } \\
(0.23 \mathrm{wt} \%) \\
2.11 \mathrm{~g} / \mathrm{L} \mathrm{Sr}\left(\mathrm{NO}_{3}\right)_{2} \\
1.6 \mathrm{~g} / \mathrm{LNaMnO} \mathrm{MnO}_{4} \\
0.51 \mathrm{~g} / \mathrm{L} \mathrm{H}_{2} \mathrm{O}_{2}\end{array}$ & $\begin{array}{c}0.60 \mathrm{~g} / \mathrm{L} \text { sludge } \\
2.12 \mathrm{~g} / \mathrm{L} \mathrm{Sr}\left(\mathrm{NO}_{3}\right)_{2} \\
1.6 \mathrm{~g} / \mathrm{L} \mathrm{NaMnO}_{4} \\
0.51 \mathrm{~g} / \mathrm{L} \mathrm{H}_{2} \mathrm{O}_{2}\end{array}$ & 0.26 \\
\hline Test 2 & $\begin{array}{c}8.44 \mathrm{~g} / \mathrm{L} \text { sludge } \\
(1.29 \mathrm{wt} \%) \\
7.8 \mathrm{~g} / \mathrm{L} \mathrm{MST}\end{array}$ & $\begin{array}{l}8.44 \mathrm{~g} / \mathrm{L} \text { sludge } \\
7.8 \mathrm{~g} / \mathrm{L} \text { MST }\end{array}$ & 0.673 & $\begin{array}{c}8.44 \mathrm{~g} / \mathrm{L} \text { sludge } \\
(3.28 \mathrm{wt} \%) \\
29.79 \mathrm{~g} / \mathrm{L} \mathrm{Sr}\left(\mathrm{NO}_{3}\right)_{2} \\
22.53 \mathrm{~g} / \mathrm{L} \mathrm{NaMnO} \mathrm{MnO}_{4} \\
7.21 \mathrm{~g} / \mathrm{L} \mathrm{H}_{2} \mathrm{O}_{2}\end{array}$ & $\begin{array}{c}8.45 \mathrm{~g} / \mathrm{L} \text { sludge } \\
29.79 \mathrm{~g} / \mathrm{L} \mathrm{Sr}\left(\mathrm{NO}_{3}\right)_{2} \\
22.53 \mathrm{~g} / \mathrm{L} \mathrm{NaMnO} \\
7.21 \mathrm{~g} / \mathrm{L} \mathrm{H}_{2} \mathrm{O}_{2}\end{array}$ & 2.00 \\
\hline Test 3 & $\begin{array}{c}30 \mathrm{~g} / \mathrm{L} \text { sludge } \\
(4.5 \mathrm{wt} \%) \\
27.5 \mathrm{~g} / \mathrm{L} \text { MST }\end{array}$ & $\begin{array}{l}30 \mathrm{~g} / \mathrm{L} \text { sludge } \\
27.5 \mathrm{~g} / \mathrm{L} \text { MST }\end{array}$ & 0.094 & $\begin{array}{c}30 \mathrm{~g} / \mathrm{L} \text { sludge } \\
(11.7 \mathrm{wt} \%) \\
105.8 \mathrm{~g} / \mathrm{L} \mathrm{Sr}\left(\mathrm{NO}_{3}\right)_{2} \\
79.98 \mathrm{~g} / \mathrm{L} \mathrm{NaMnO} \mathrm{MnO}_{4} \\
25.57 \mathrm{~g} / \mathrm{L} \mathrm{H}_{2} \mathrm{O}_{2}\end{array}$ & $\begin{array}{c}28.38 \mathrm{~g} / \mathrm{L} \text { sludge } \\
105.8 \mathrm{~g} / \mathrm{L} \mathrm{Sr}\left(\mathrm{NO}_{3}\right)_{2} \\
79.98 \mathrm{~g} / \mathrm{L} \mathrm{NaMnO} \mathrm{NaMn}_{4} \\
34.94 \mathrm{~g} / \mathrm{L} \mathrm{H}_{2} \mathrm{O}_{2}\end{array}$ & 9.12 \\
\hline
\end{tabular}

We prepared the feed for the first test by taking a 12-liter sample of the $5.6 \mathrm{M}$ supernate and adding $7.2 \mathrm{~g}$ of sludge (i.e., $0.6 \mathrm{~g} / \mathrm{L}$ ) and $6.6 \mathrm{~g}$ of MST (i.e., $0.55 \mathrm{~g} / \mathrm{L}$ ). Following the addition of MST, we mixed the feed slurry for 24 hours and collected a sample, which we filtered with a 0.45 -micron syringe filter and prepared for analysis. Personnel then filtered the slurry through the SpinTek unit. The system initially operated at standard operating conditions with a transmembrane pressure of $40 \mathrm{psi}$ and a rotor speed of $1170 \mathrm{rpm}$. We also obtained additional data points at transmembrane pressures of $30 \mathrm{psi}$ and $50 \mathrm{psi}$. 
Following the filtration test, personnel added $94.10 \mathrm{~g}$ of dry sludge, raising the concentration to $8.44 \mathrm{~g} / \mathrm{L}$ and added $85.8 \mathrm{~g}$ of MST slurry, raising the concentration to $7.8 \mathrm{~g} / \mathrm{L}$. We then repeated the test protocol without the 24-hour mixing time. Following the filtration test, personnel added $258.72 \mathrm{~g}$ of dry sludge raising the concentration to $30.0 \mathrm{~g} / \mathrm{L}$ and added $237.6 \mathrm{~g}$ of MST slurry raising the concentration to $27.5 \mathrm{~g} / \mathrm{L}$. We again repeated the test protocol without the 24-hour mixing time. The sludge additions simulated increasing the level of insoluble solids by concentration therefore; no additional mixing time was deemed necessary prior to filtration.

We prepared the feed for the tests using permanganate by combining the remainder of the 5.6 M supernate sample (approximately 12-L) with $7.2 \mathrm{~g}$ (i.e., $0.6 \mathrm{~g} / \mathrm{L}$ ) of sludge, $25.39 \mathrm{~g}$ (i.e., $0.01 \mathrm{M}$ ) of strontium nitrate, and $19.2 \mathrm{~g}$ (i.e., $0.01 \mathrm{M}$ ) of sodium permanganate. We then added hydrogen peroxide, $6.12 \mathrm{~g}$ (i.e., 0.015 M), subsurface to a well-mixed tank. Following the addition of sludge, strontium nitrate, permanganate and peroxide, the feed solution continued mixing. After 15 minutes, we collected a small sample from the feed tank, which we filtered with a 0.45 -micron syringe filter, to confirm that the permanganate reacted completely (i.e., no residual purple color to the supernate). The solution no longer appeared purple. We mixed for an additional 45 minutes, collected a sample that was syringe filtered and started the filter test. We initially operated the filter at standard operating conditions of 40 psig transmembrane pressure and a rotor speed of $1170 \mathrm{rpm}$. We obtained additional data at transmembrane pressures of 30 and 50 psi as well, measuring flux throughout testing.

Following the first filtration test, we added an additional $94.188 \mathrm{~g}$ (i.e., total concentration $8.44 \mathrm{~g} / \mathrm{L}$ ) of dry sludge, $332.14 \mathrm{~g}$ (i.e., to $1.69 \mathrm{M}$ total) of strontium nitrate, $251.15 \mathrm{~g}$ (i.e., to $1.91 \mathrm{M}$ total) of sodium permanganate, and $80.4 \mathrm{~g}$ (i.e., to $2.54 \mathrm{M}$ total) of hydrogen peroxide. During the addition of peroxide, we observed some foaming of the feed. After mixing the feed and testing for reaction completion, we processed the slurry through the rotary filter.

We increased the solids concentration again by adding $239.135 \mathrm{~g}$ of dry sludge (i.e., to $28.38 \mathrm{~g} / \mathrm{L}$ ), $911.71 \mathrm{~g}$ (i.e., to $0.5 \mathrm{M}$ total) of strontium nitrate, $689.38 \mathrm{~g}$ (i.e., to $0.5 \mathrm{M}$ total) of sodium permanganate, and 220.3 $\mathrm{g}$ (i.e., to $0.75 \mathrm{M}$ total) of hydrogen peroxide. Technicians added an additional $112.5 \mathrm{~g}$ of hydrogen peroxide to complete the reaction. The additional amount proved necessary due to possible decomposition of the peroxide. To provide enough volume for the final addition of chemicals, we filtered approximately 3 liters of feed to a separate bottle prior to the addition of the sludge and chemicals. We reduced the addition rate of the peroxide to minimize foaming.

Throughout this report we refer to the insoluble solids feed concentration as the target values listed in Table 5. Given the high uncertainty in the analytical method for determining total solids content, we believe the calculated values better reflect the slurry composition.

\subsection{Results}

\subsection{Simulant}

Figure 2 shows the filtration rate results from testing the 0.1 -micron rotary microfilter with simulant at a nominal MST/sludge feed solids concentration of $0.09 \mathrm{wt} \%$ insoluble solids. As expected, filtration rates dropped with an increase in solids content of the feed solution. The largest flux came with 50 psi transmembrane pressure and the lowest solids concentration. 
WSRC-TR-2003-00030, Rev. 0

Page 12 of 33

February 2003

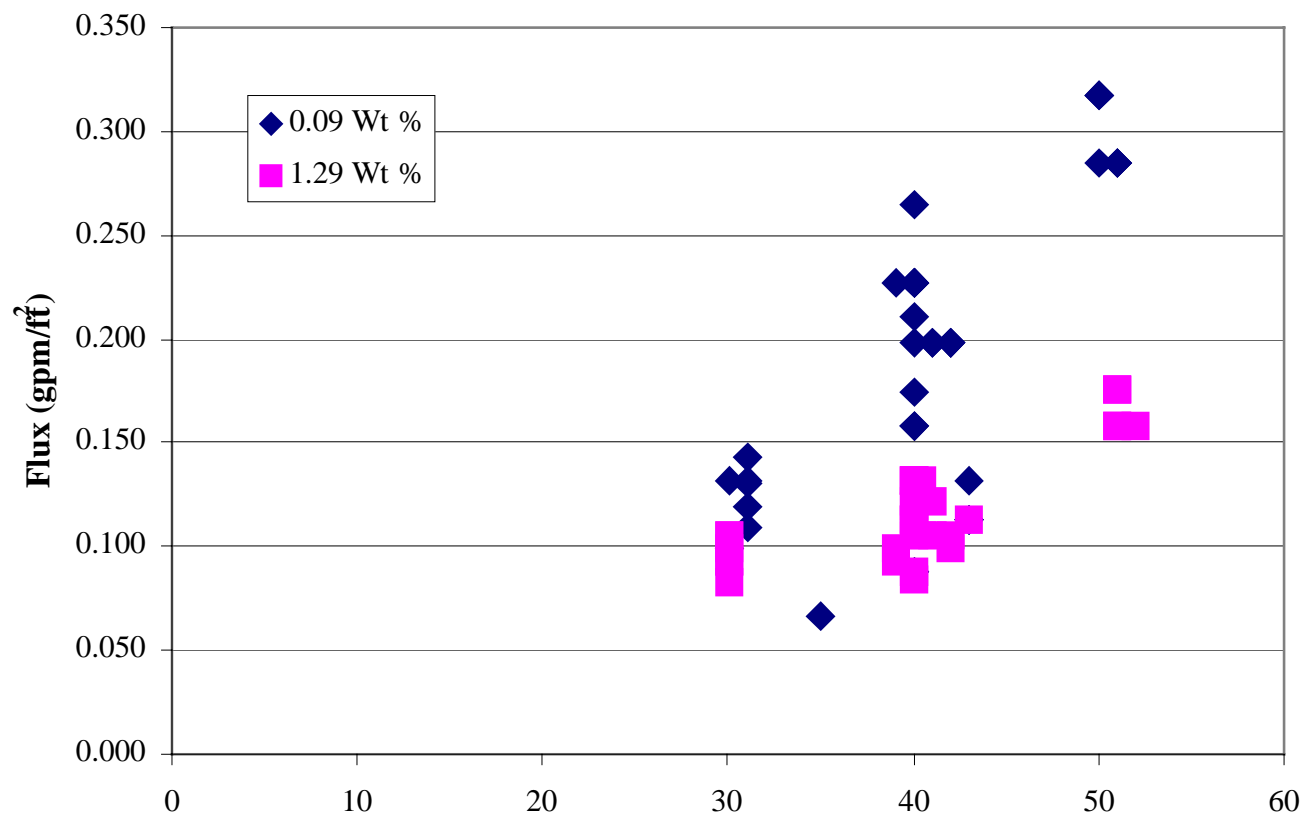

Transmembrane Pressure (psi)

Figure 2. Rotary 0.1-Micron Filter Using SRS Simulant and MST

Table 6 compares these results with testing done at the vendor ${ }^{9}$ with SRS simulant using the 0.1-micron ceramic membrane rather than a stainless-steel membrane. The results show good agreement between the data sets. At the higher solids loadings, the vendor test produced a higher flux. It is unclear whether the differences in the flux rate are due to the difference in membrane material or insoluble solids loading.

Table 6. Comparison of Vendor ${ }^{9}$ and SRTC Simulant Test Data

\begin{tabular}{|c|c|c|c|c|c|}
\hline \multicolumn{3}{|c|}{$\begin{array}{l}\text { Vendor Test (2001) } \\
\text { 0.1-micron ceramic }\end{array}$} & \multicolumn{3}{c|}{ SRTC } \\
\hline $\begin{array}{c}\text { 0.1-micron stainless-steel } \\
\begin{array}{c}\text { Solids } \\
(\mathrm{wt} \%)\end{array}\end{array}$ & $\begin{array}{c}\text { TMP } \\
(\mathrm{psi})\end{array}$ & $\begin{array}{c}\text { Flux } \\
(\mathrm{gpm} / \mathrm{ft} 2)\end{array}$ & $\begin{array}{c}\text { Solids } \\
\text { Concentration } \\
(\mathrm{wt} \%)\end{array}$ & $\begin{array}{c}\text { TMP } \\
(\mathrm{psi})\end{array}$ & $\begin{array}{c}\text { Flux } \\
(\mathrm{gpm} / \mathrm{ft} 2)\end{array}$ \\
\hline 0.05 & 40 & 0.21 & 0.09 & 40 & 0.21 \\
\hline 1.03 & 40 & 0.15 & 1.29 & 40 & 0.11 \\
\hline
\end{tabular}

Following completion of the initial filtration experiments, we cleaned the 0.1 -micron filter by rinsing the system with dilute oxalic acid $(0.5 \mathrm{M})$ for approximately 10 minutes and then inhibited water for approximately one hour. Figure 3 shows a new disk and the disk after this cleaning procedure. 


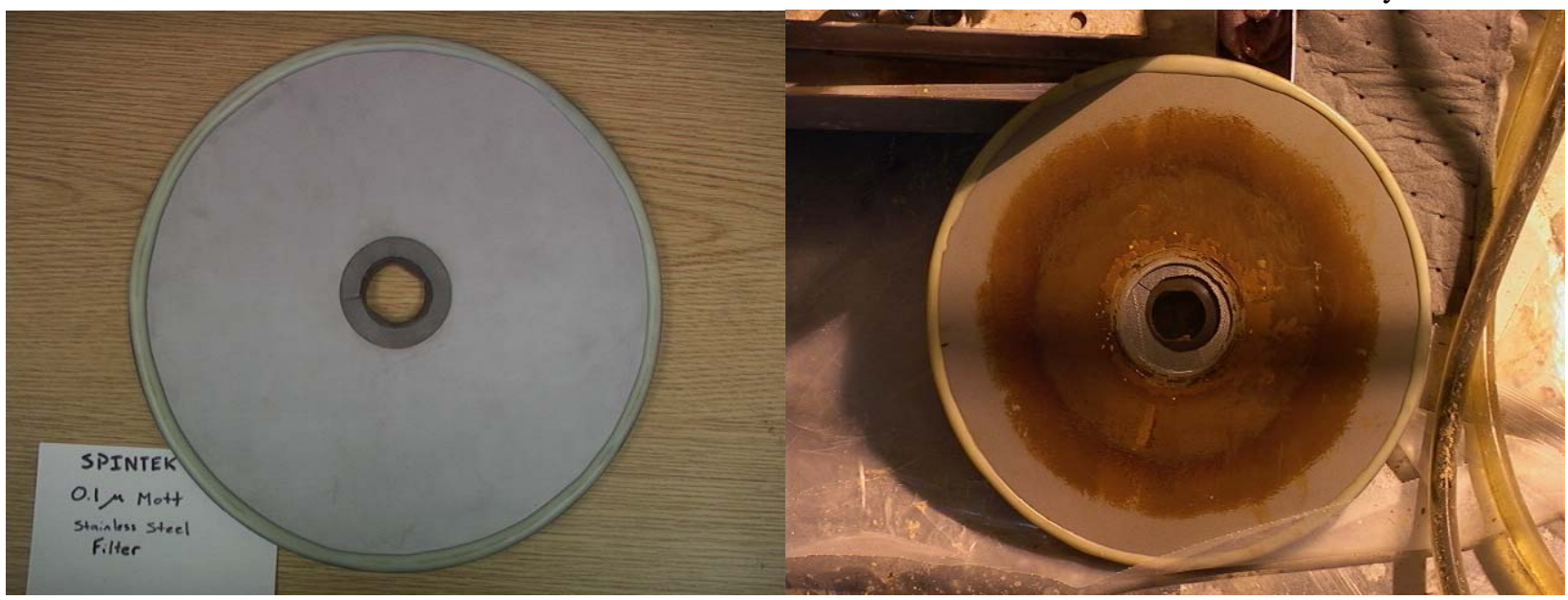

Figure 3. SpinTek 0.1-Micron Filter Disks, New and After Cleaning

Next, we replaced the 0.1 -micron filter disk with the 0.5 -micron filter disk and repeated the prior tests. We operated for about 6 hours with flux measurements taken every 10 minutes.

Figure 4 shows the filtration rates using the 0.5 -micron filter with the nominal $1.29 \mathrm{wt} \% \mathrm{MST} / \mathrm{sludge}$ slurry.

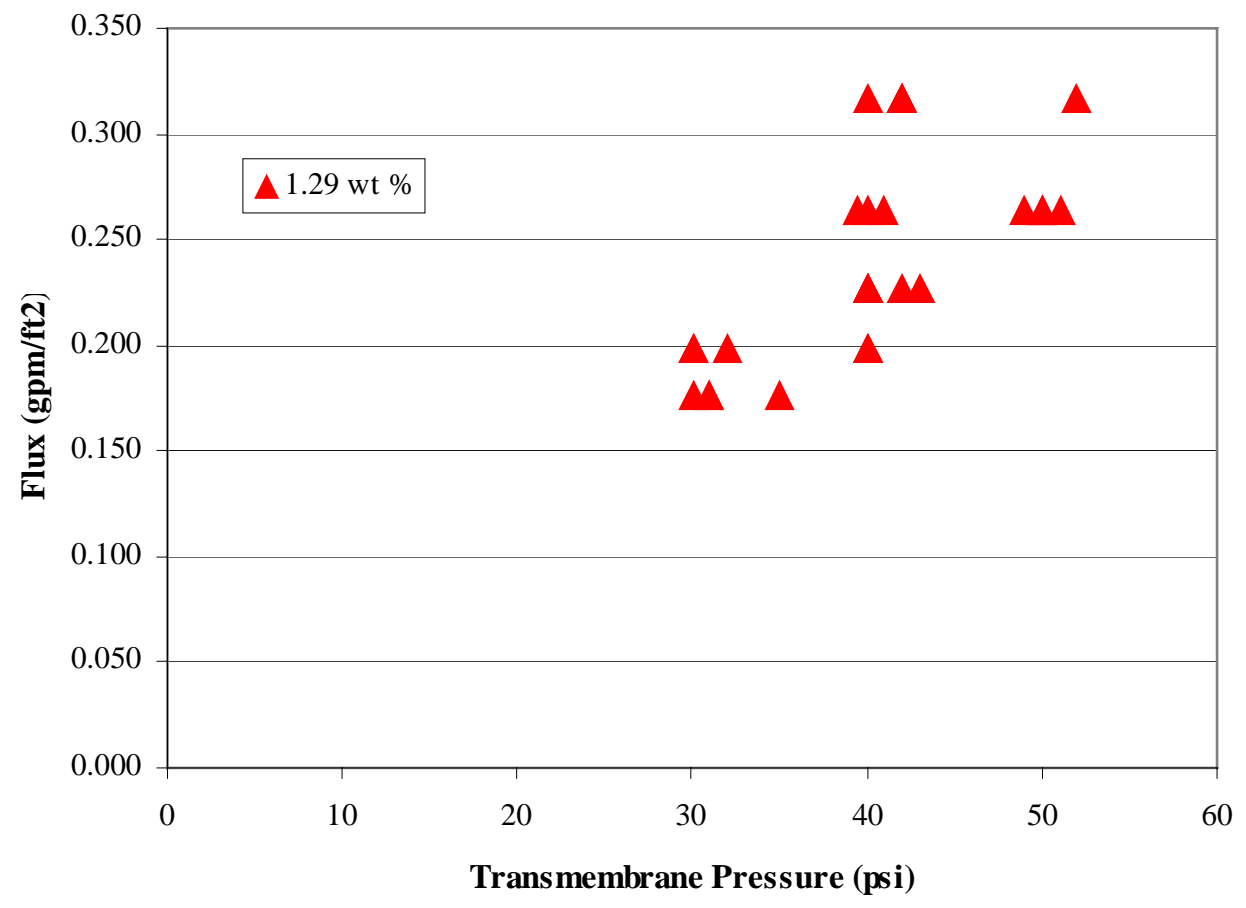

Figure 4. Rotary 0.5-Micron Filter Using SRS Simulant and MST

Figure 5 shows the 0.5 -micron filter compared to the 0.1 -micron filter at both insoluble solids loading using simulant. The filtration rates proved approximately two times higher for the 0.5 -micron filter than for the 0.1-micron filter at a comparable solids loading. 
WSRC-TR-2003-00030, Rev. 0

Page 14 of 33

February 2003

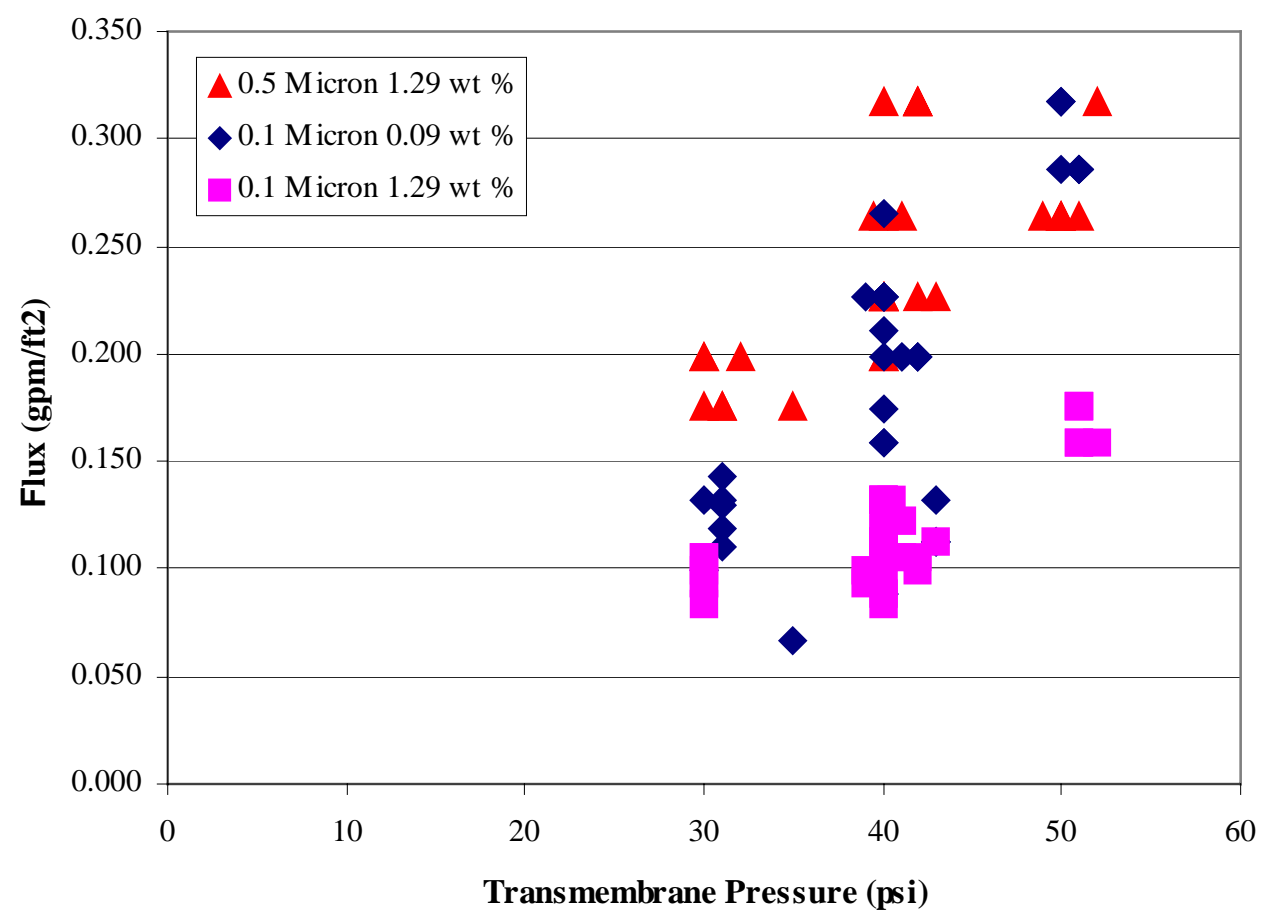

Figure 5. Rotary 0.1- and 0.5-Micron Filters Using SRS Simulant and MST

The difference in the filtration rates for the 0.1- and 0.5-micron rotary filters are more pronounced than the filtration rates for the corresponding cross-flow filters. The prior tests with a cross-flow filter showed better flux for the 0.1 -micron cross-flow filter as compared to the 0.5 -micron cross-flow filter. ${ }^{19}$ There are three possible explanations for the differences in flux between the 0.1 - and 0.5 -micron filters. First, for any filter, the resistance is primarily the sum of the resistance through the filter cake and the resistance of the filter itself. For the SpinTek configuration, the additional shear from the rotary action reduces the layer of solids on the filter. By reducing the cake of solids on the surface of the membrane, the flowpath resistance in the filter provides a larger contribution to the total resistance to filtration and, hence, we observe a large variation with pore-size. For the conventional cross-flow configuration, the cake properties play a larger role and the variance of flux with pore-size of the media appears less significant. The second possible explanation is that in prior experiments the authors tested the 0.5 -micron filter before the 0.1 -micron filter. The 0.5 -micron filter likely removed the small particles from the feed. Therefore, the 0.1 -micron filter processed a feed stream with fewer particles and the slurry proved easier to process. The third explanation is the possibility of a problem with the permeate carrier.

Figure 6 shows a comparison of the 0.5 -micron rotary filter to the 0.5 -micron cross-flow filter using SRS simulant at similar solids levels. Even at a slightly higher solids content, the flux rate for the rotary filter proves 4 to 6 times that of the cross-flow filter. The increase results from the additional shear across the filter surface reducing the caking of solids. 
WSRC-TR-2003-00030, Rev. 0

Page 15 of 33

February 2003

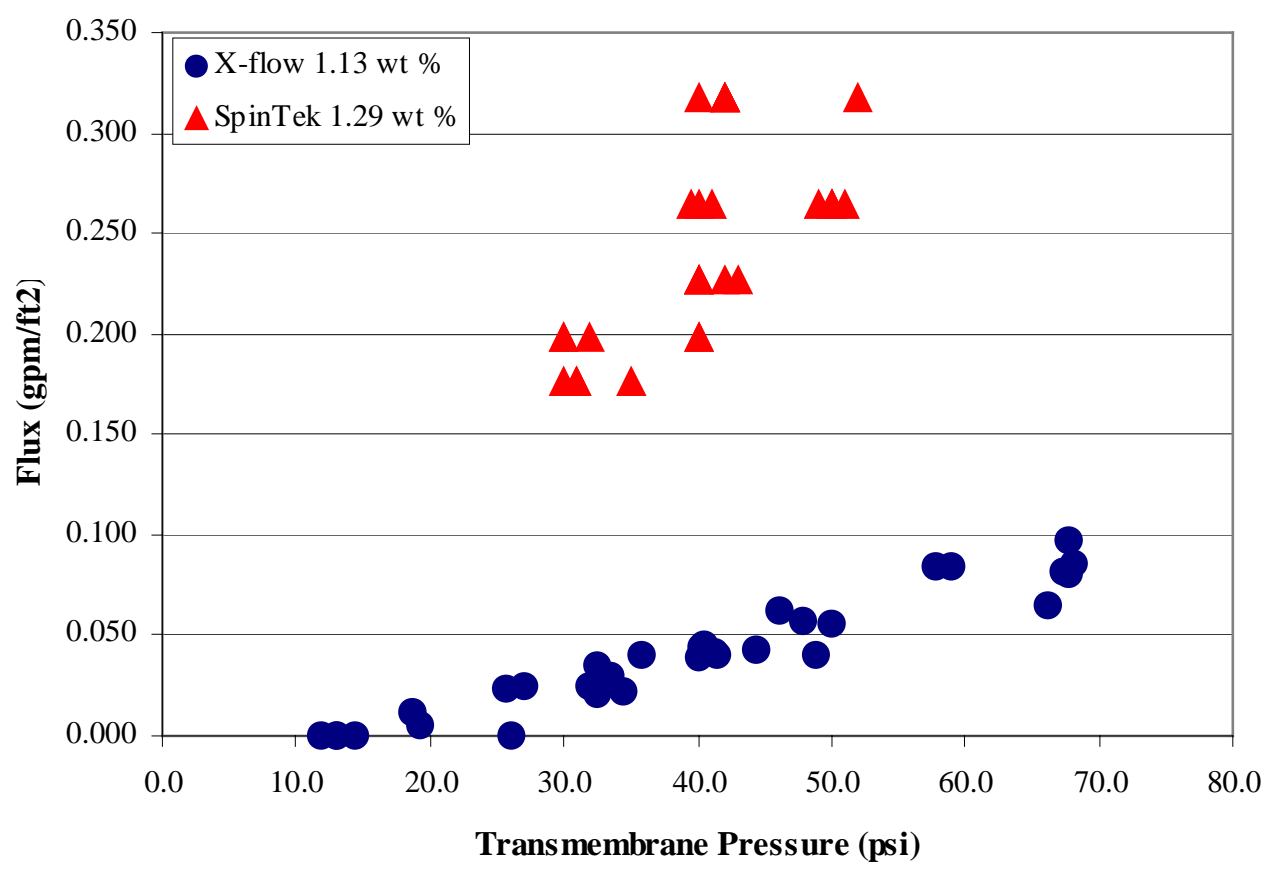

Figure 6. Comparison of Rotary and Cross-Flow 0.5-Micron Filters with Simulant and MST

Figure 7 compares the flux rates for the 0.1 -micron rotary filter to the 0.5 -micron cross-flow filter. At comparable insoluble solids loadings, the resulting filtration rates for the rotary filter proved 2 to 3 times that of the cross-flow filter. In general, the 0.5 -micron filter appears better behaved than the 0.1 -micron filter with the possible exception of the data at $1.29 \mathrm{wt} \%$. The data correlates more nearly linear with pressure.

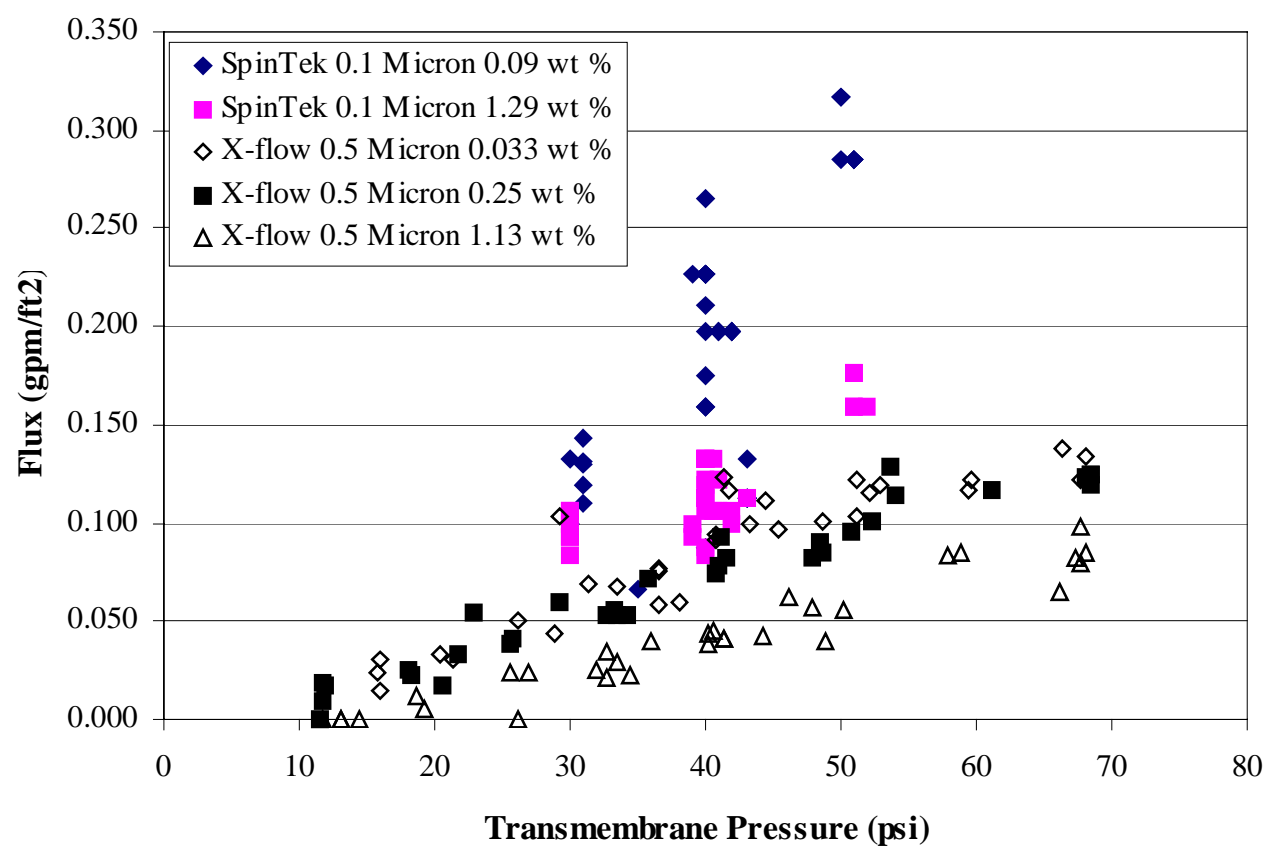

Figure 7. Rotary 0.1-Micron Filter and Cross-Flow 0.5-Micron Filter Using SRS Simulant and MST 


\subsection{Testing With Actual Waste}

\subsubsection{1-Micron Disk with MST}

After completing the simulant testing and cleaning the unit, we installed the 0.1-micron stainless steel filter disk. We installed the unit in the shielded cells and verified that the system operated using water.

Figure 8 shows the results of testing with the 0.1 -micron filter disk with the 0.09 wt $\% \mathrm{MST} /$ sludge slurry. Flux rates ranged from 0.06 to $0.12 \mathrm{gpm} / \mathrm{ft}^{2}$, depending on the transmembrane pressure.

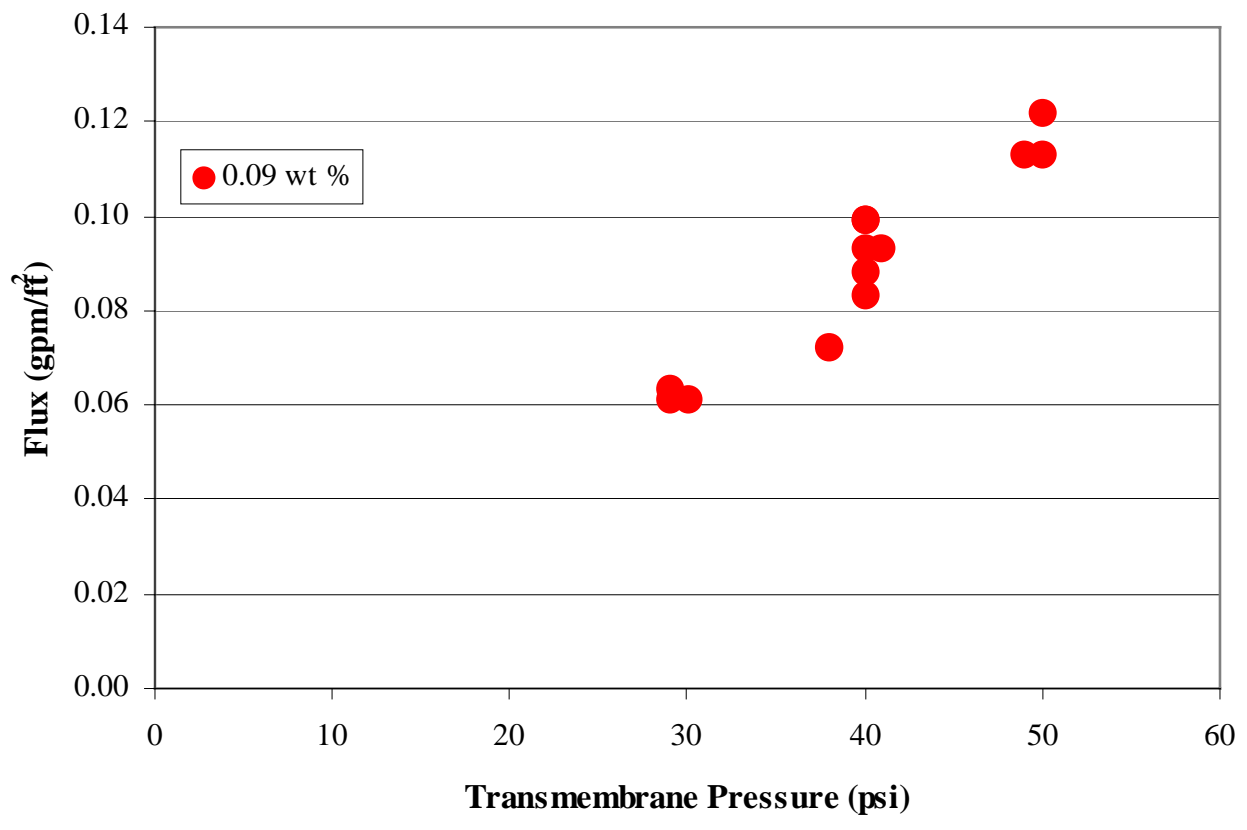

\section{Figure 8. Rotary 0.1-Micron Filter Using Actual Waste and MST}

Figure 9 shows filtration rates for the $1.29 \mathrm{wt} \%$ slurry in comparison to that for the 0.09 wt $\%$ slurry. Although the overall insoluble solids content increased from $0.09 \mathrm{wt} \%$ to $1.29 \mathrm{wt} \%$, the filtration rate remained unchanged. In fact; for the tests at the higher pressure, the filtration rate for the more concentrated slurry slightly exceeded that for the less concentrated slurry. This observation does not agree with expectations based on previous testing ${ }^{9}$. 
WSRC-TR-2003-00030, Rev. 0

Page 17 of 33

February 2003

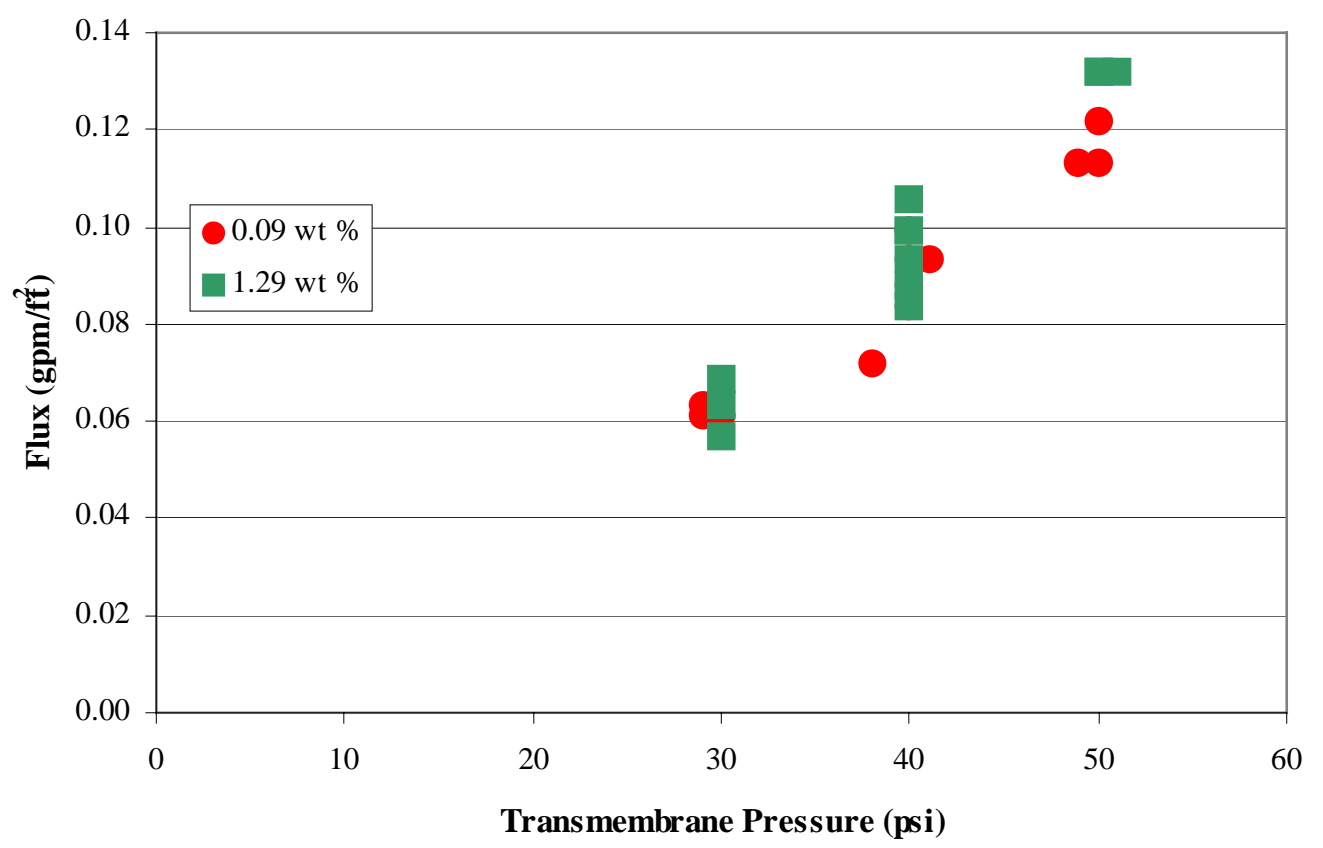

Figure 9. Rotary 0.1-Micron Filter Using Acutal Waste at 0.09 and 1.29 wt \% and MST

Figure 10 compares the filtration rates for the $4.5 \mathrm{wt} \%$ slurry to the previous results. The filtration rate dropped for the $4.5 \mathrm{wt} \%$ feed with values ranging from 0.04 to $0.09 \mathrm{gpm} / \mathrm{ft}^{2}$.

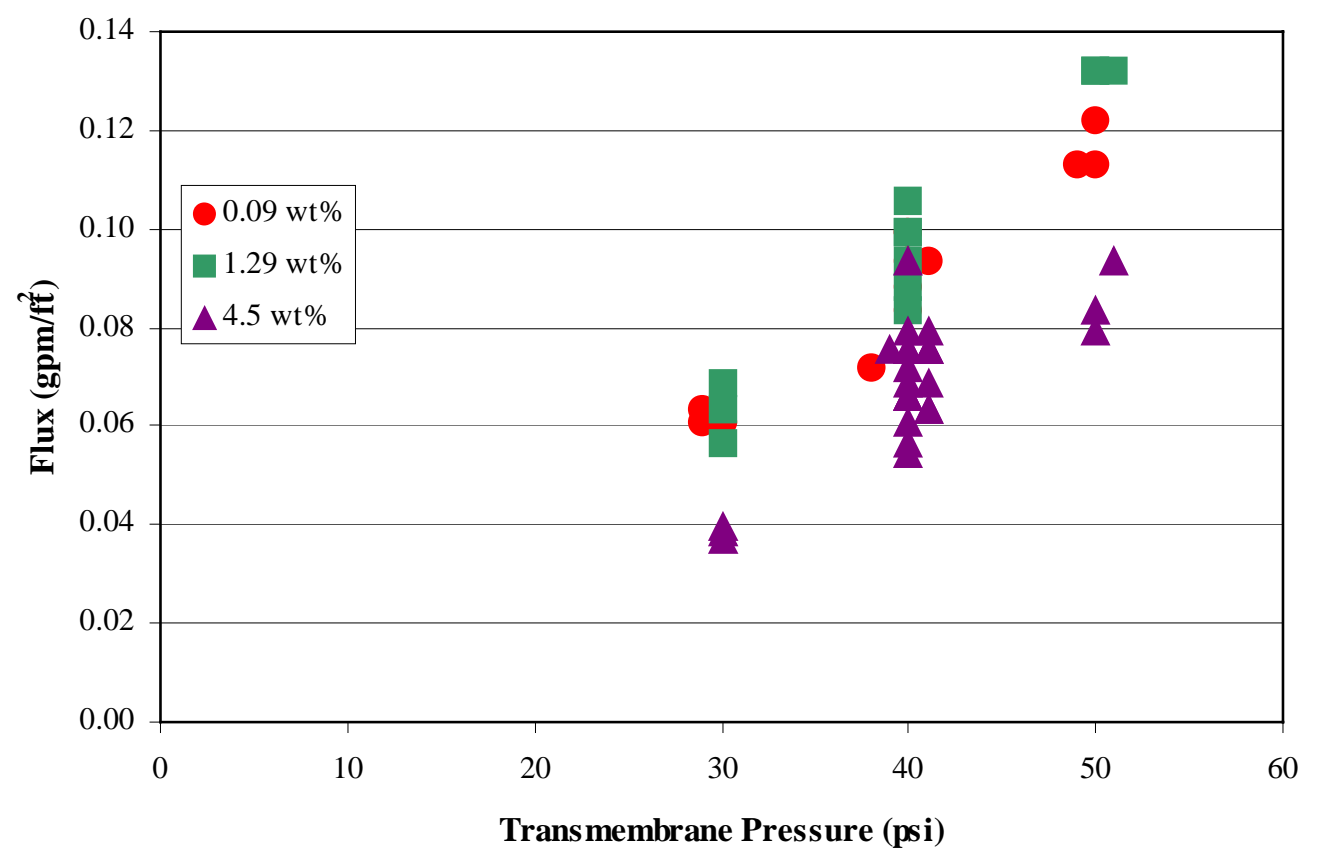

Figure 10. Rotary 0.1-Micron Filter Using Acutal Waste and MST at All Waste Loadings

Also, the actual waste filtration rates with the rotary microfilter proved lower than expected based on the earlier tests with simulated waste. Previous testing with cross-flow filters indicates that the actual waste typically had higher fluxes than the simulants. ${ }^{7}$ As seen in Figure 11, fluxes for simulant testing exceeded 
those for the actual waste testing, particularly at the lower solids concentration. Additionally, we observed little variation in the filtration rates for the actual waste in contrast to that observed with the simulant testing where the increase in insoluble solids made a dramatic difference.

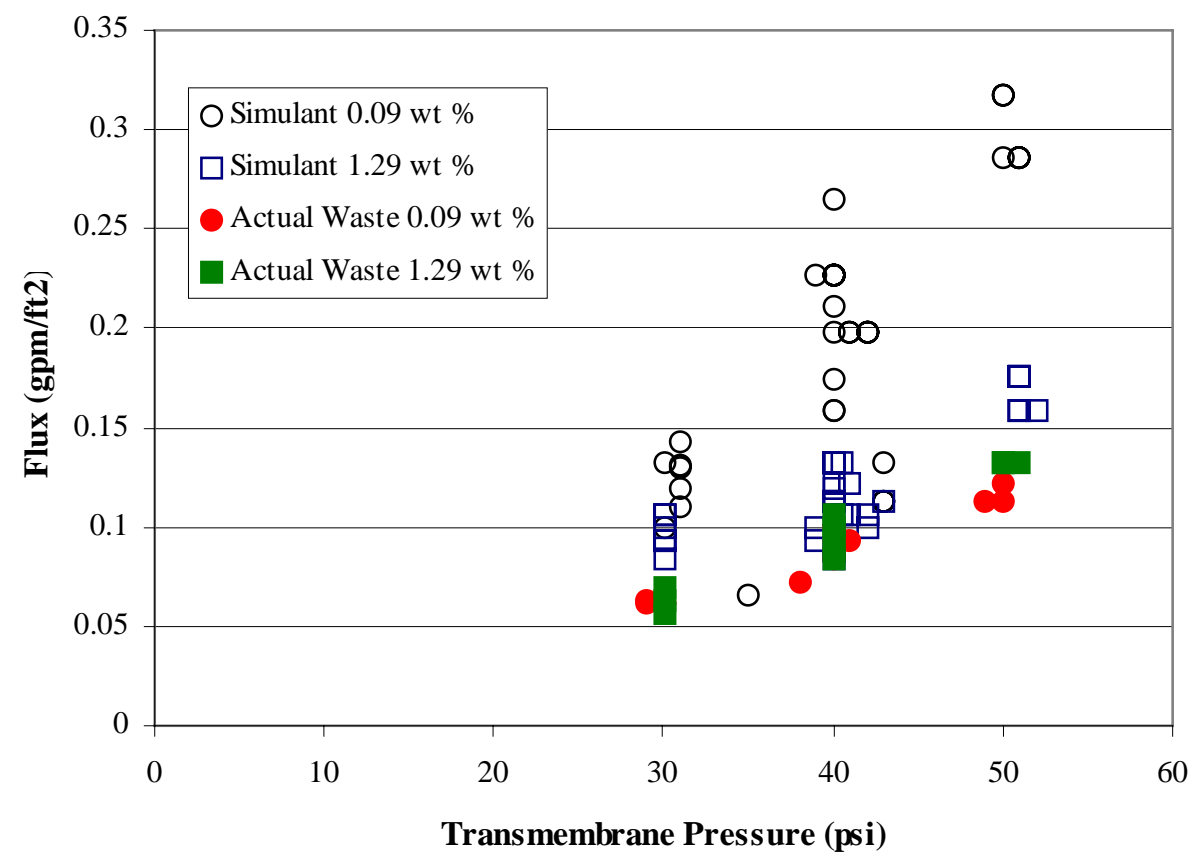

Figure 11. Comparison of Simulant and Actual Waste Using MST and a 0.1-Micron Rotary Filter

When compared to the cross-flow filter, the filtration rates of the rotary filter did not show marked improvement during actual waste testing as they did during the simulant testing. Figure 12 compares the filtration rate for the 0.1-micron rotary filter and 0.5-micron cross-flow filter for the 0.09 wt \% slurry.

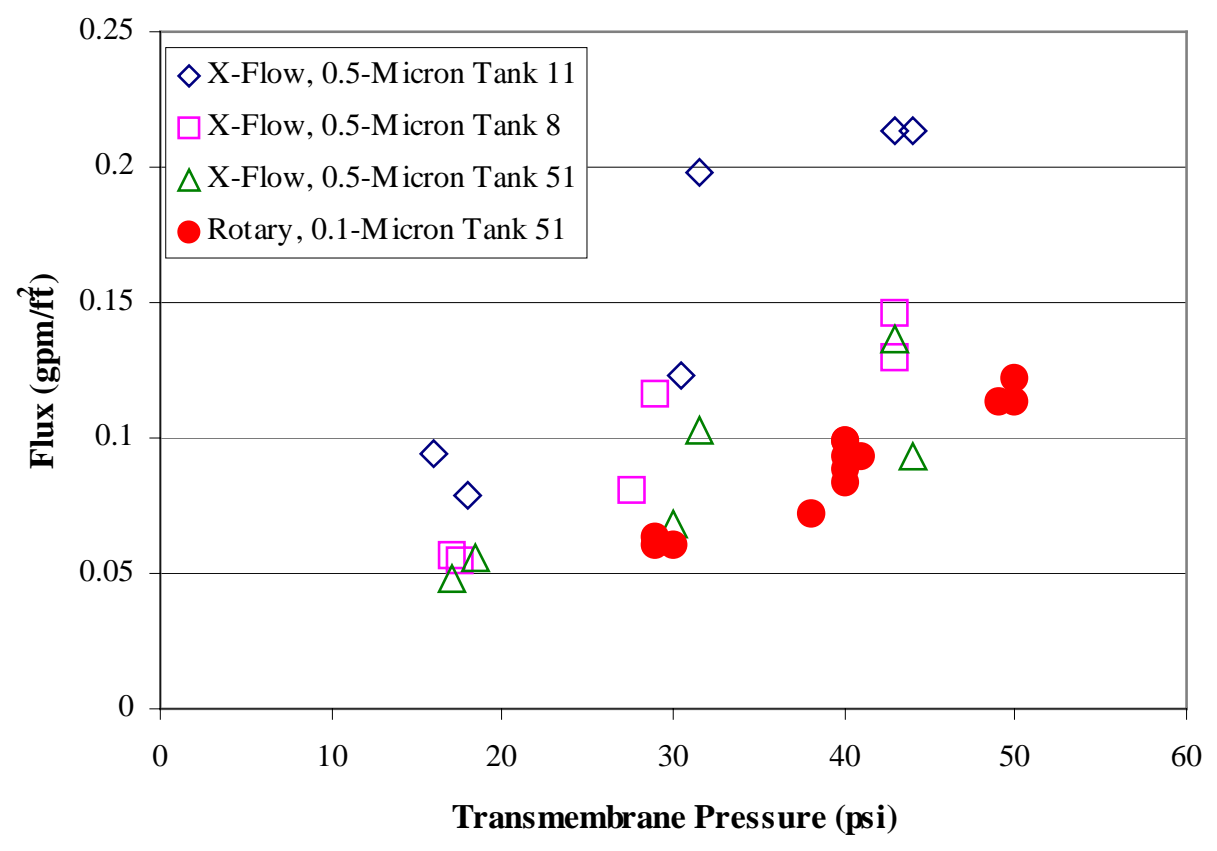

Figure 12. Comparison of 0.1-Micron Rotary and 0.5-Micron Cross-Flow Filters at 0.09 wt \% Insoluble Solids with Actual Waste and MST 
The filtration rates equaled or fell below those of the cross-flow filter. Even though the rotary filter test used a smaller pore-size filter, we expected higher fluxes at this concentration due to the advantage of high surface shear. Figure 13 includes the 0.1-micron cross-flow filtration rates for comparison.

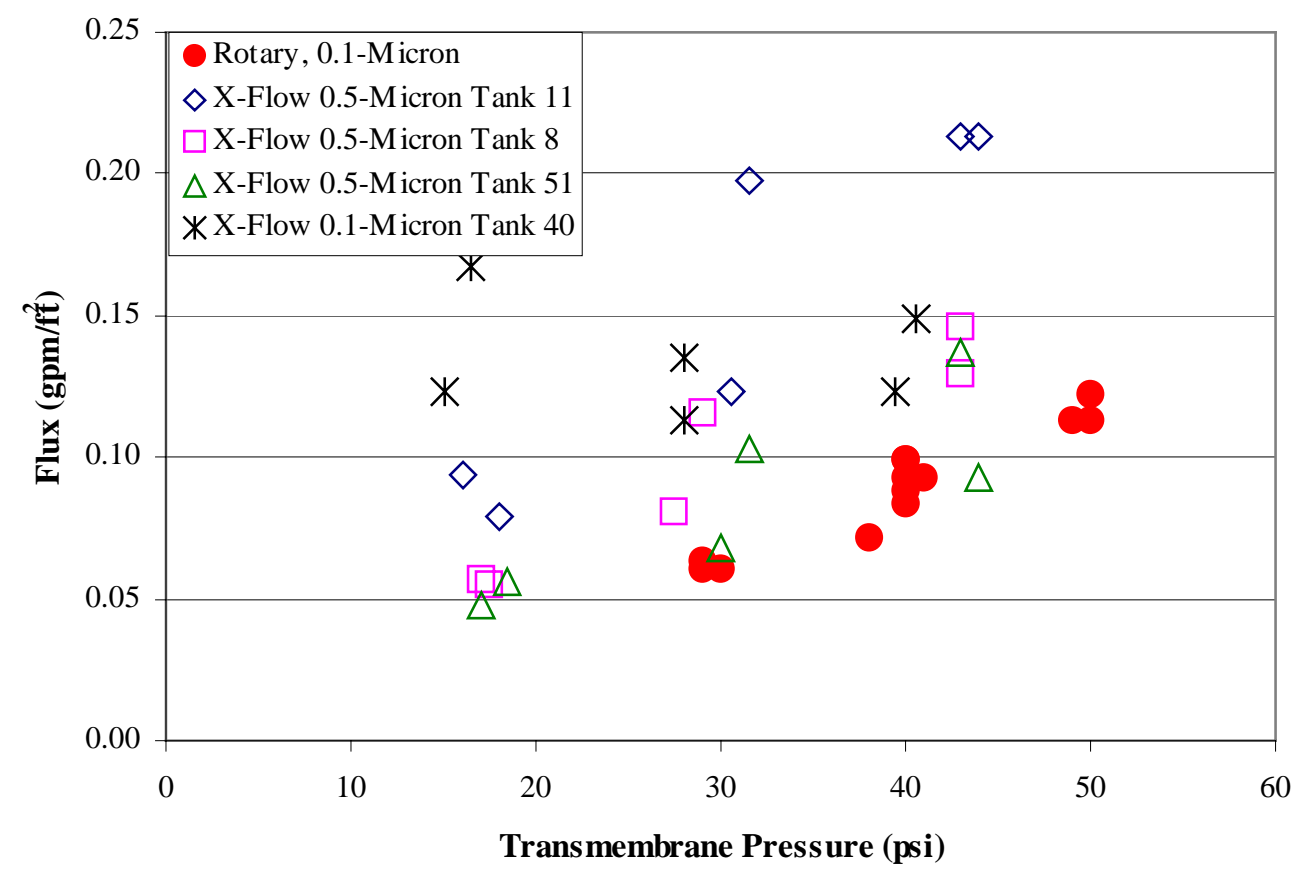

Figure 13. Comparsion of 0.1-Micron Rotary Filter and 0.5-Micron Cross-Flow Filter at 0.09 wt \% Insoluble Solids with Actual Waste and MST

As shown earlier, the increase in insoluble solids concentration from $0.09 \mathrm{wt} \%$ to $1.29 \mathrm{wt} \%$ resulted in little effect on the filtration rate for the rotary filter for actual waste. This resulted in an overall greater filtration rate during rotary filtration of $1.29 \mathrm{wt} \%$ solids compared to the cross-flow filter at similar conditions. Figure 14 shows a comparison of the flux rates at an insoluble solids loading of $1.29 \mathrm{wt} \%$. 
WSRC-TR-2003-00030, Rev. 0

Page 20 of 33

February 2003

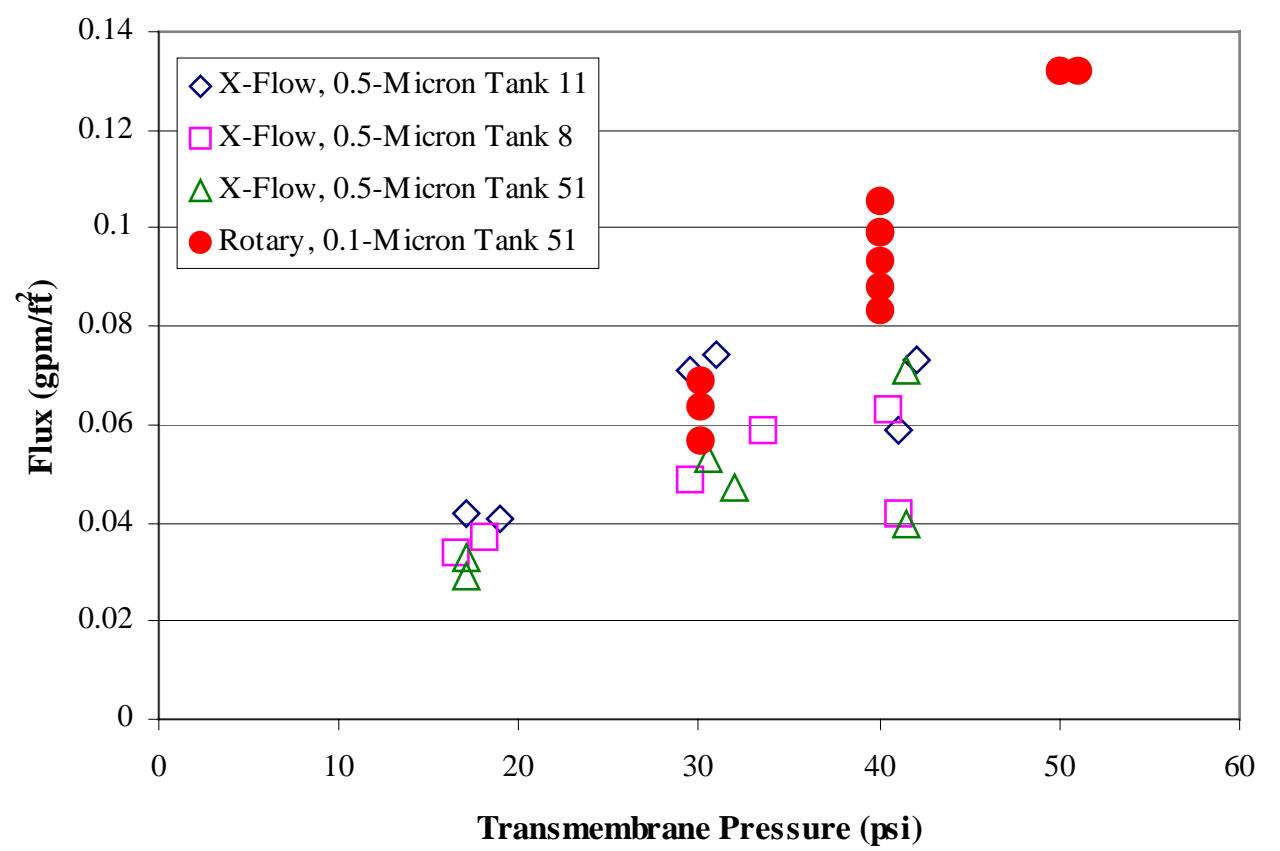

Figure 14. Comparison of 0.1-Micron Rotary Filter and 0.5-Micron Cross-Flow Filter at 1.29 wt \% Insoluble Solids with Actual Waste and MST

As the insoluble solids level increased to $4.5 \mathrm{wt} \%$, the rotary filter gave fluxes that generally exceeded those for the cross-flow filter. Figure 15 illustrates the filtration rates for the 0.1 -micron rotary filter and 0.5 -micron cross-flow filter at $4.5 \mathrm{wt} \%$ insoluble solids.

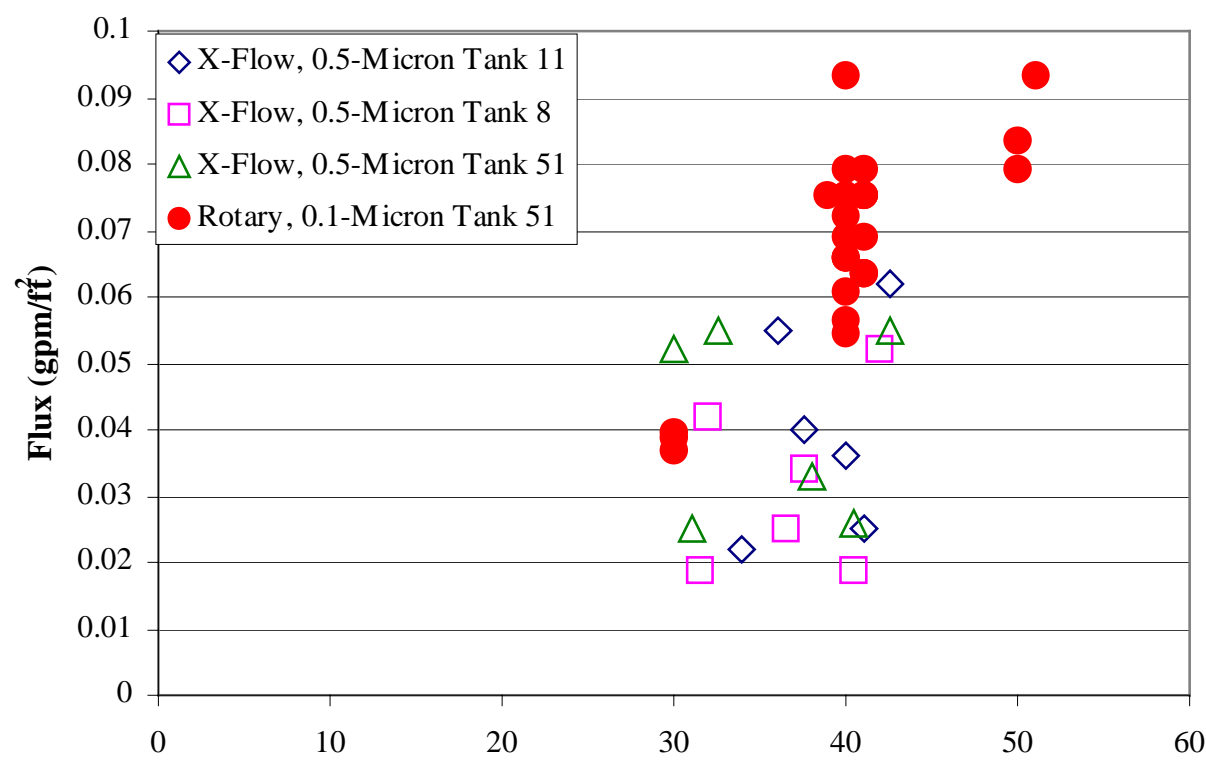

Transmembrane Pressure (psi)

Figure 15. Comparison of 0.1-Micron Rotary and 0.5-Micron Cross-Flow Filters at 4.5 wt \% Insoluble Solids with Actual Waste and MST 
Overall, filtration rates using the 0.1-micron rotary filter show an improvement over the cross-flow filter, which appears most pronounced at the higher solids content levels. However, these results proved lower than anticipated based on previous testing as well as the simulant runs from this study.

After the completion of the MST feed testing, we rinsed the unit with water. Filtration rates of the water with no added solids measured approximately $0.088 \mathrm{gpm} / \mathrm{ft}^{2}$. This value agreed with the early MST filtration rates at the $0.09 \mathrm{wt} \%$ solids loading. This flux is lower than expected for typical rinse water flux. The rinse water did contain residual solids; therefore, at the time, we considered the values reasonable although lower than we expected from previous experience with the simulant testing.

Testing with the 0.1-micron filter disk continued to show deterioration. The fact that the rinse water provided the same flux as the first slurry provides evidence of the deterioration. This behavior resembles data from simulant testing when the flow decreased due to the constriction of the permeate carrier. The data suggests that the temporary modification of inserting a metal mesh over the plastic mesh had degraded during testing. This degradation likely occurred due to heat and radiation softening the plastic allowing it to fill in the gaps of the metal mesh and constricting the flow path.

We collected filtrate samples throughout testing and analyzed them for strontium and select actinides. Table 7 provides the results. The samples collected from the feed solution and filtered with the syringe filter met the design specification ${ }^{20}$ for strontium, plutonium and neptunium. The filtrate samples from the SpinTek unit met the design specification for plutonium and neptunium, but did not for strontium.

Table 7. Radionuclide Removal with MST Treatment

\begin{tabular}{|c|c|c|c|c|c|c|c|c|}
\hline Sample & $\begin{array}{c}{ }^{90} \mathbf{S r} \\
(\mathbf{d p m} / \mathbf{m L})\end{array}$ & $\begin{array}{c}\mathbf{P u} \\
(\mathbf{d} \mathbf{p m} / \mathbf{m L})\end{array}$ & $\begin{array}{c}\mathbf{U} \\
(\boldsymbol{\mu} \mathbf{g} / \mathbf{L})\end{array}$ & $\begin{array}{c}\mathbf{N p} \\
(\mathbf{d p m} / \mathbf{m L})\end{array}$ & $\begin{array}{c}{ }^{90} \mathbf{S r} \\
(\mathbf{D F})\end{array}$ & $\begin{array}{c}\mathbf{P u} \\
(\mathbf{D F})\end{array}$ & $\begin{array}{c}\mathbf{U} \\
(\mathbf{D F})\end{array}$ & $\begin{array}{c}\mathbf{N p} \\
(\mathbf{D F})\end{array}$ \\
\hline Pre-Strike & $1,282,000$ & 10,200 & 2725 & 23.7 & N/A & N/A & N/A & N/A \\
\hline Syringe Filter & 99,000 & 2010 & 1707 & 5.4 & 12.9 & 5.1 & 1.6 & 4.4 \\
\hline $\begin{array}{c}0.09 \text { wt } \% \\
\text { Filtrate }\end{array}$ & 413,000 & 1730 & 1357 & 4.3 & 3.1 & 5.9 & 2.0 & 5.5 \\
\hline $\begin{array}{c}0.09 \text { wt } \% \\
\text { Filtrate }\end{array}$ & 324,000 & 3050 & 1333 & $<3.1$ & 4.0 & 3.3 & 2.0 & $>7.7$ \\
\hline $\begin{array}{c}\text { Design } \\
\text { Specification }^{20}\end{array}$ & 111,000 & 50,000 & N/A & 83 & N/A & N/A & N/A & N/A \\
\hline
\end{tabular}

$$
\mathrm{N} / \mathrm{A}=\text { not applicable }
$$

The strontium removal in the rotary microfilter test with sludge and MST did not meet process requirements. The authors identified five plausible reasons for the failure to meet the design specification for strontium-90: the feed did not equilibrate, filter breakthrough, MST batch variability, MST particle attrition, and sludge particle attrition.

Lack of feed equilibration is unlikely to be the dominant cause of the poor strontium removal observed. The feed equilibrated for 58 days prior to the MST strike. The syringe sample collected just prior to the start of the filter test and a few hours prior to the first filtrate sample met the design specification. The strontium-90 concentration in the feed slurry for the permanganate test, which equilibrated for 72 days, showed $25 \%$ higher concentration than in the MST test.

If filter breakthrough occurred, the filtrate samples would contain much higher concentrations of plutonium and neptunium. In addition, if significant breakthrough occurred; the filtrate would contain visible solids. The filtrate samples appeared clear. 
Bolder Scientific manufactured the MST batch used for this test. The mean particle size equaled $5 \mu$, with $1.7 \%$ of the particles less than $1 \mu$, and none of the particles greater than $22 \mu$. In qualification tests, the MST produced a strontium decontamination factor of 102. ${ }^{21}$ The MST removed enough strontium to meet the process requirements in the syringe filtered samples. Batch variability is unlikely to account for the lack of adequate strontium removal observed in the rotary microfilter filtrate samples.

The high strontium concentration in the filtrate may be from MST particle attrition. Previous transmission electron microscopy (TEM) studies showed the strontium preferentially accumulates in the fibrous outer region of $\mathrm{MST}^{22}$ We do not know where the plutonium accumulates. If only the fibrous surface region of the MST fragments from the shearing and this region has high strontium loading but not high actinide loading, the strontium might pass through the filter as sorbed material on these MST fine particles, while the actinides remain principally with the inner region of the MST. This mechanism is unlikely to cause the high strontium concentrations observed in the filtrate. The strontium levels measured in the filtrate samples would require significant particle attrition and passage of particles through the filter. The filtrate appeared clear which is inconsistent with a large number of sheared particles passing through the filter disk.

The high strontium concentration in the filtrate may be from sludge particle attrition. The sludge particles contain a large source of strontium, likely present as strontium carbonate. Some of the strontium leached into the supernate while the feed equilibrated, but much of it remained "trapped" in the sludge. The feed recirculation pump and rotating filter disks produce greater shear than created by agitation within the batch contact tank, which can break apart the sludge particles. Particle size measurements from testing at pilot scale using simulated waste provide evidence of the attrition. ${ }^{23}$ When the sludge particles break apart, they can release some of the strontium which is "trapped" into the supernate. The excess MST that is present will adsorb this strontium, but the sorption process is slow. Since the isotopic dilution and permanganate precipitation occur more rapidly, the strontium that released during that test precipitated or sorbed quickly, and passed through the filter at lower concentrations - see Table 8.

\subsubsection{1-Micron Disk with Permanganate}

We performed testing with the permanganate feed solution described previously. During testing, several pumping problems arose that did not occur with the MST feed solution. At times during the testing, the pump output dropped under the target flow and pressure. We determined that the drop in pump performance resulted from plugging in the lines. Backflushing provided only a temporary fix. Due to these pumping difficulties, it proved necessary to replace both the pump outlet and pump suction lines.

Filtration of the permanganate-treated slurry with the 0.1 -micron pore-size disk also produced significantly lower flux rates than expected. Figure 16 shows the filtration rates for the permanganate feed containing 0.23 wt $\%$ solids. 
WSRC-TR-2003-00030, Rev. 0

Page 23 of 33

February 2003

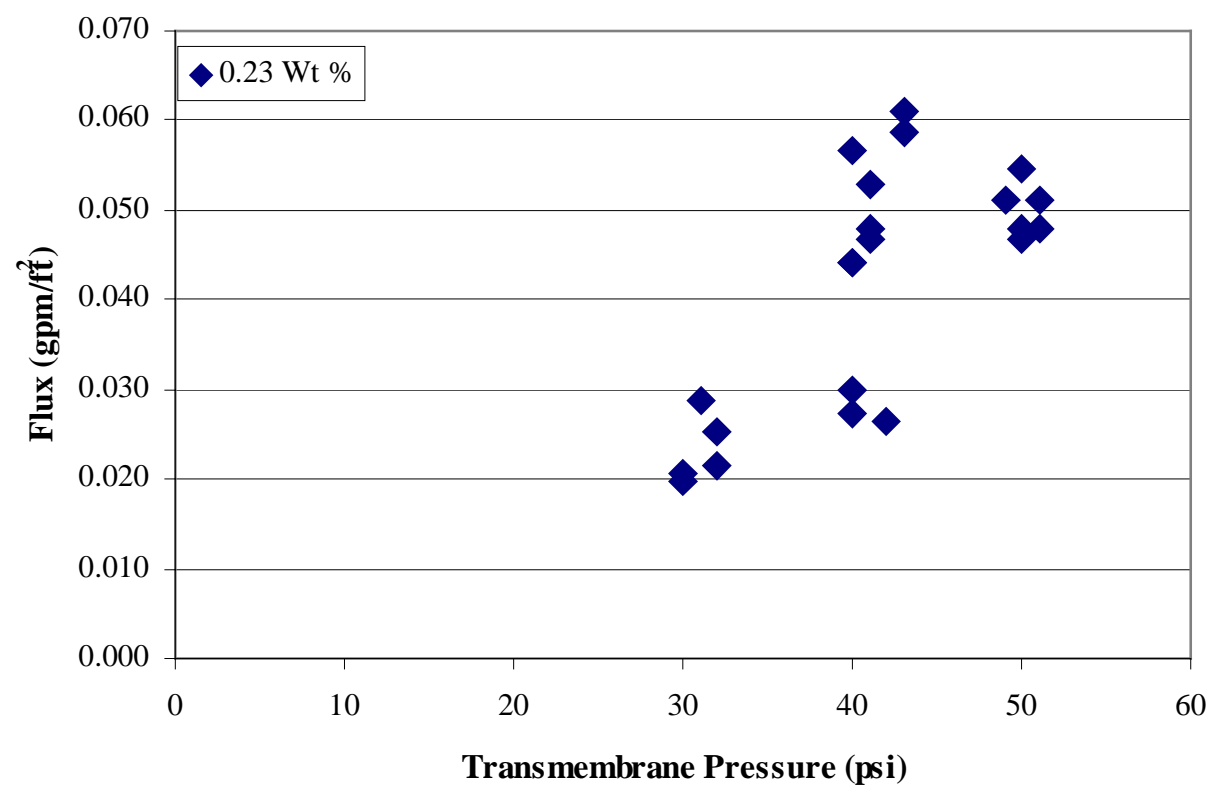

Figure 16. Rotary 0.1-Micron Filter Using Permanganate Treated Actual Waste at 0.23 wt \% Insoluble Solids

Figure 17 adds the filtration rates at the $3.28 \mathrm{wt} \%$ insoluble solids loading to those of the $0.23 \mathrm{wt} \%$. When the concentration of insoluble solids increased from $0.23 \mathrm{wt} \%$ to $3.28 \mathrm{wt} \%$, the filtration rate did not change, similar to the results of the MST testing. On average, the flow rate increased with the increase in solids, which is contrary to expectations.

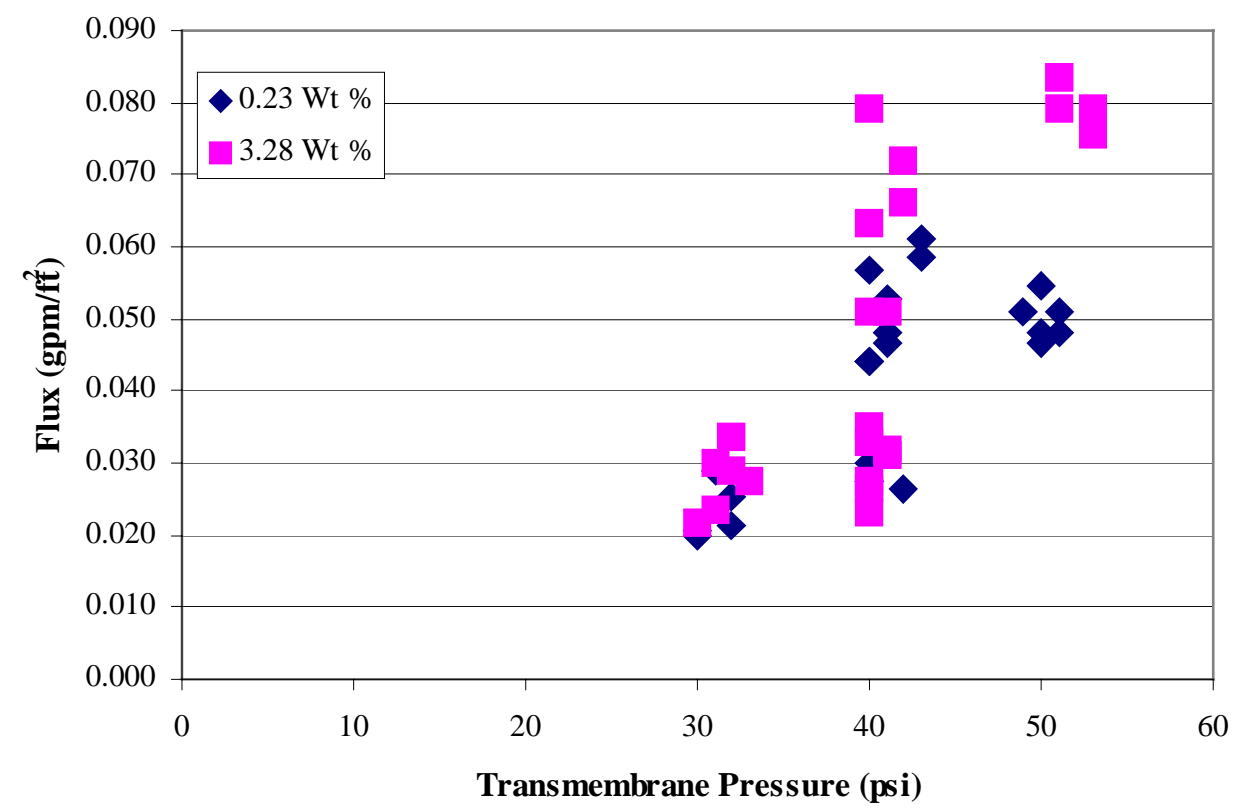

Figure 17. Rotary 0.1-Micron Filter Using Permanganate Treated Actual Waste with 0.23 and 3.28 wt \% Insoluble Solids

Figure 18 includes the filtration rates for the $11.7 \mathrm{wt} \%$ insoluble solids slurry with the previous tests with permanganate. With the additional insoluble solids, flux rates dropped to approximately $0.01 \mathrm{gpm} / \mathrm{ft}^{2}$. Flux rates changed little with the change in transmembrane pressure. 


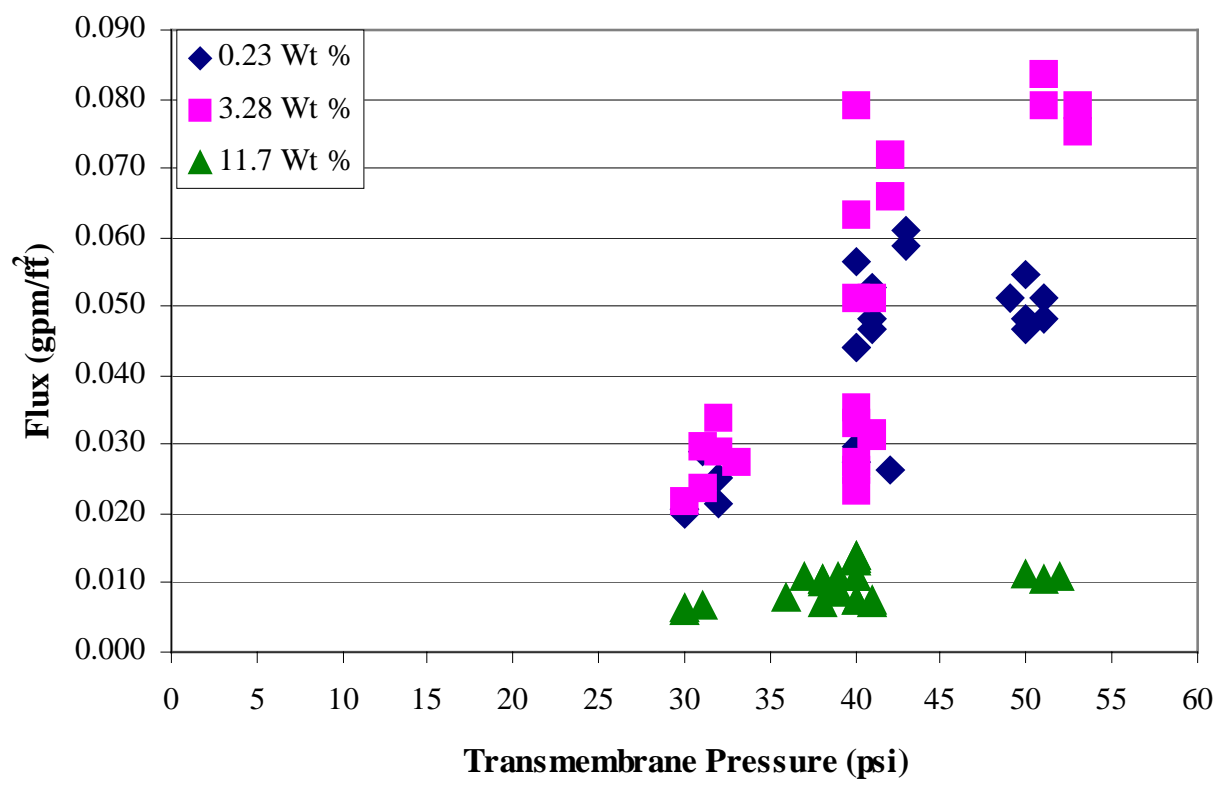

Figure 18. Rotary 0.1-Micron Filter Using Permanganate Treated Actual Waste at All Solids Loadings

Collectively, the results for both the MST- and permanganate-treated waste indicate a reduction in the available flow path for the permeate. Figure 19 shows that the starting filtration rate for the lowest solids content permanganate feed fell below the filtration rate of the highest solids concentration MST experiment, indicating an inconsistency in the performance of the filter disk.

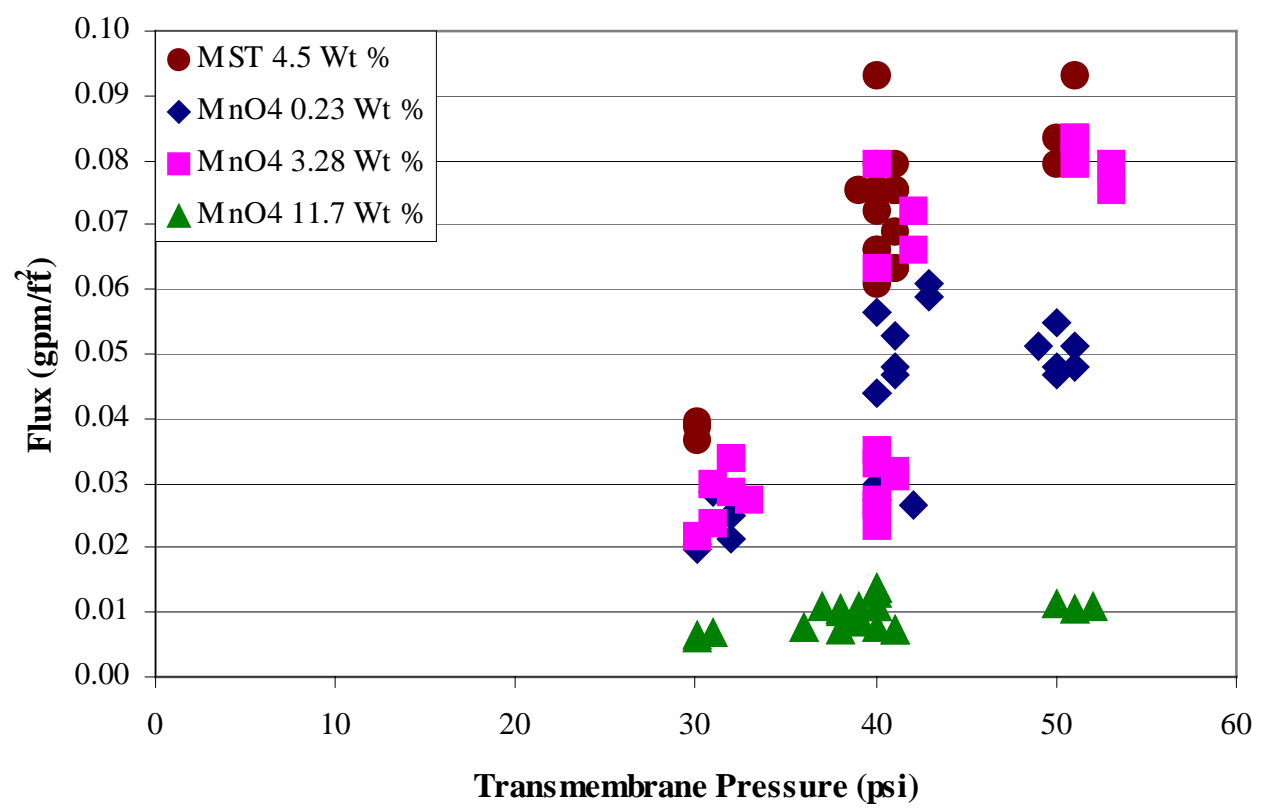

Figure 19. Comparison of High Solids MST to $\mathrm{MnO}_{4}$ at all Solids Levels using a 0.1-Micron Rotary Filter 
The SpinTek filter disks used in the testing consisted of Mott sintered stainless steel sheets cut and mounted on the typical SpinTek filter disk substrate. Filter disks contained a Ryton ${ }^{\mathrm{TM}}$ disk as the base, or core, material. The design then includes a flow carrying mesh, termed the permeate carrier, mounted to the sides of the Ryton ${ }^{\mathrm{TM}}$ disk. The fabrication adds the sintered-metal filter sheet on the mesh with an epoxy bead joining the filter sheet to the Ryton ${ }^{\mathrm{TM}}$ plate. Figure 20 shows a cut-away sketch of a disk.

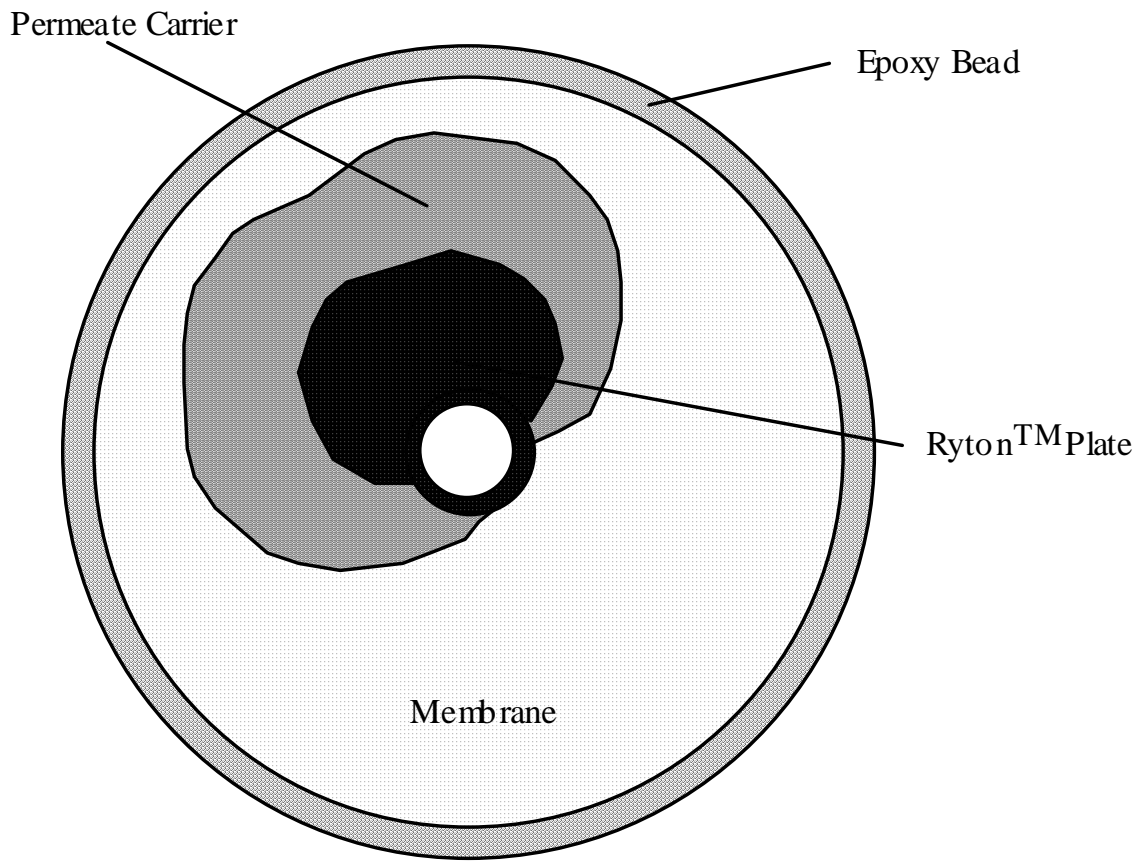

Figure 20. SpinTek Filter Disk Construction

The vendor constructed the 0.1-micron filter disk using a polypropylene mesh. Early in testing with simulated waste, we found that this mesh would compress and deform under the load of tightening the filter shaft nut. This compression of the flow carrier restricted the flowpath of permeate. Variations in filtrate rate proved dramatic ranging from $1500 \mathrm{~mL} / \mathrm{min}$ of filtrate to less than $50 \mathrm{~mL} / \mathrm{min}$, depending on the torque applied to the nut. To maintain a consistent filtrate flow path, SRTC researchers added shims to the filter disk. We initially used shims $10 \mathrm{mil}$ in thickness. Flow rates increased significantly and appeared reproducible. We also tested 20 mil shims, but these showed no improvement in filtrate flows over the 10mil shims. We held discussions with the vendor as to providing a permanent design modification for the disks. Collectively, we agreed to have the vendor insert a stainless steel mesh to maintain the flow path at the point of compression. The vendor constructed all future disks - including the 0.1-micron pore-size disks for pilot testing at the University of South Carolina and the 0.5-micron pore-size disks used in subsequent actual waste experiments - using the stainless mesh throughout the disk.

The steel mesh insert provided a consistent and reproducible filtrate rate during simulant testing. We believe that during operation at elevated temperatures and in the radiation fields, the original polypropylene mesh in the 0.1-micron pore-size disks softened and progressively blocked the flow paths through the stainless steel mesh insert.

After completion of the actual waste experiments with the 0.1 -micron pore-size filter, we cleaned the filter system by running 6 liters of water for approximately 1 hour at a pressure of 40 psi. Water filtration rates measured approximately $0.088 \mathrm{gpm} / \mathrm{ft}^{2}$. Technicians then removed the filter disk and replaced it with a $0.5-$ micron pore-size filter disk. Figure 21 shows the condition of the 0.1 -micron pore-size disk as the filter upon disassembly. 


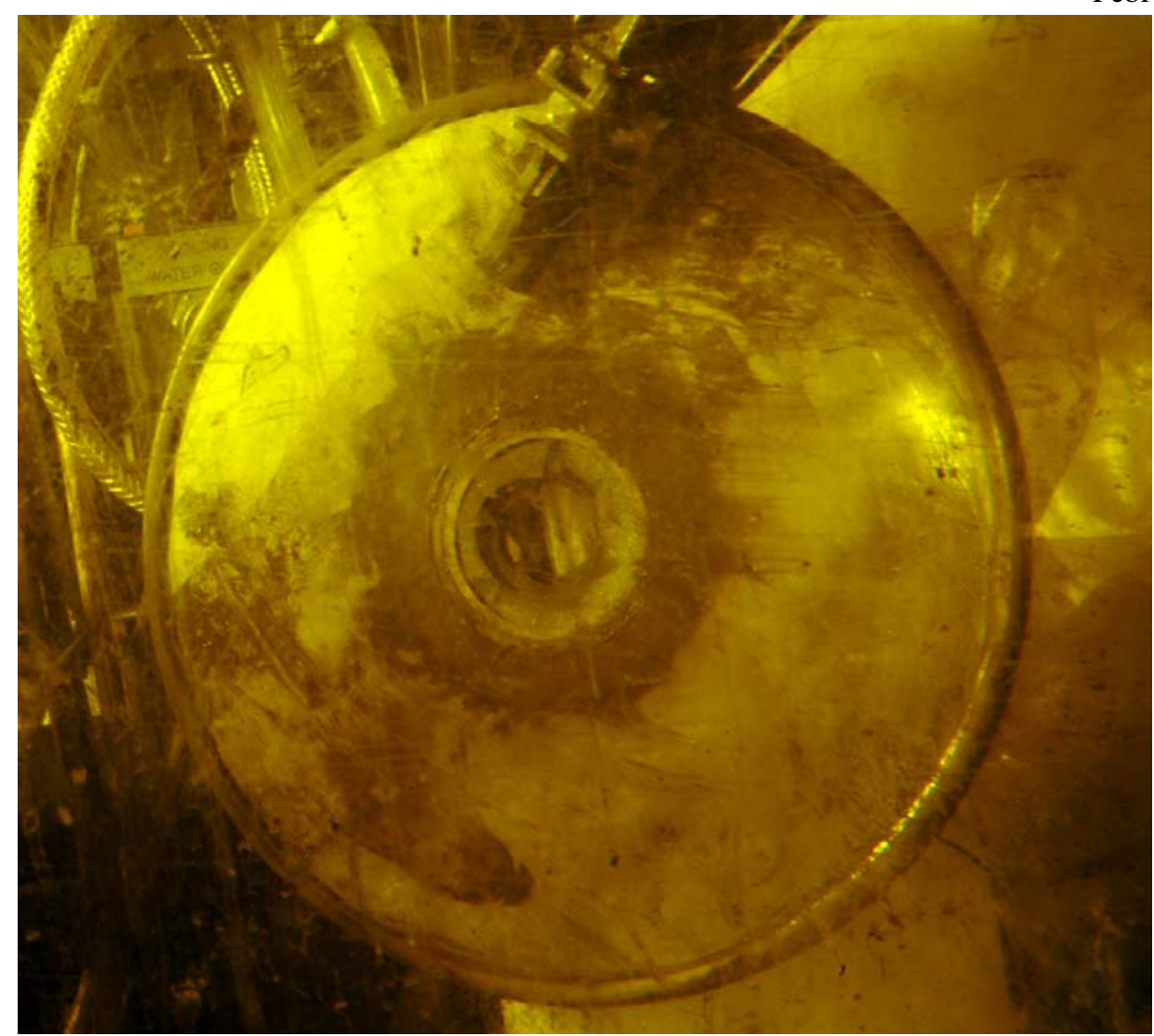

\section{Figure 21. Picture of the 0.1-Micron Filter After Testing With Actual Waste}

The surface of the disk appeared generally clean with most solids visible toward the center of the disk. The solids appear as the darker areas on the disk surface in Figure 21.

Personnel collected filtrate samples throughout testing and analyzed them to determine extent of alpha and strontium removal. Table 8 shows the analysis of the filtrate. Both the syringe filter samples and the SpinTek filtrate samples met the requirements for strontium, plutonium and neptunium. As observed for the MST samples, the SpinTek filtrate contained higher concentrations of strontium than the syringefiltered samples. The permanganate treatment proved more effective - in both efficiency and speed - at removing strontium than the MST. Also, the permanganate removed plutonium faster but with less efficiency. Nevertheless, the permanganate treatment met the design specification for the Salt Waste Processing Facility.

Table 8. Radionuclide Removal From Permanganate Treatment

\begin{tabular}{|c|c|c|c|c|c|c|c|c|}
\hline Sample & $\begin{array}{c}{ }^{\mathbf{9 0}} \mathbf{S r} \\
(\mathbf{d p m} / \mathbf{m L})\end{array}$ & $\begin{array}{c}\mathbf{P u} \\
(\mathbf{d p m} / \mathbf{m L})\end{array}$ & $\begin{array}{c}\mathbf{U} \\
(\mu \mathbf{g} / \mathbf{L})\end{array}$ & $\begin{array}{c}\mathbf{N p} \\
(\mathbf{d p m} / \mathbf{m L})\end{array}$ & $\begin{array}{c}{ }^{\mathbf{9 0}} \mathbf{S r} \\
(\mathbf{D F})\end{array}$ & $\begin{array}{c}\mathbf{P u} \\
(\mathbf{D F})\end{array}$ & $\begin{array}{c}\mathbf{U} \\
(\mathbf{D F})\end{array}$ & $\begin{array}{c}\mathbf{N p} \\
(\mathbf{D F})\end{array}$ \\
\hline Pre-Strike & $1,621,206$ & 5900 & 5465 & 22.6 & N/A & N/A & N/A & N/A \\
\hline Syringe Filter & 14,004 & 3630 & 4911 & 6.4 & 115.8 & 1.6 & 1.1 & 3.6 \\
\hline $\begin{array}{c}0.23 \text { wt \% } \\
\text { Filtrate }\end{array}$ & 25,529 & 2330 & 3794 & 3.3 & 63.5 & 2.5 & 1.4 & 7.0 \\
\hline $\begin{array}{c}0.23 \text { wt \% } \\
\text { Filtrate }\end{array}$ & 34,168 & 1510 & 4526 & 6.2 & 47.4 & 3.9 & 1.2 & 3.7 \\
\hline $\begin{array}{c}\text { Design } \\
\text { Specification }^{20}\end{array}$ & 111,000 & 50,000 & N/A & 83 & N/A & N/A & N/A & N/A \\
\hline
\end{tabular}




\subsubsection{5-Micron Disk with MST and Permanganate}

February 2003

We installed a 0.5-micron pore-size filter disk of the improved design. This disk contained the stainless steel permeate carrier mesh. We used this disk to filter the slurries containing the highest insoluble solids concentration of both the MST and permanganate-derived solids. Filtration rates proved significantly higher than the previous experiments, including the initial tests with simulated waste. Filtration rates remained high through several hours of testing. Figure 22 shows the filtration rates for the 0.5 -micron pore-size rotary filter using the MST and permanganate slurries.

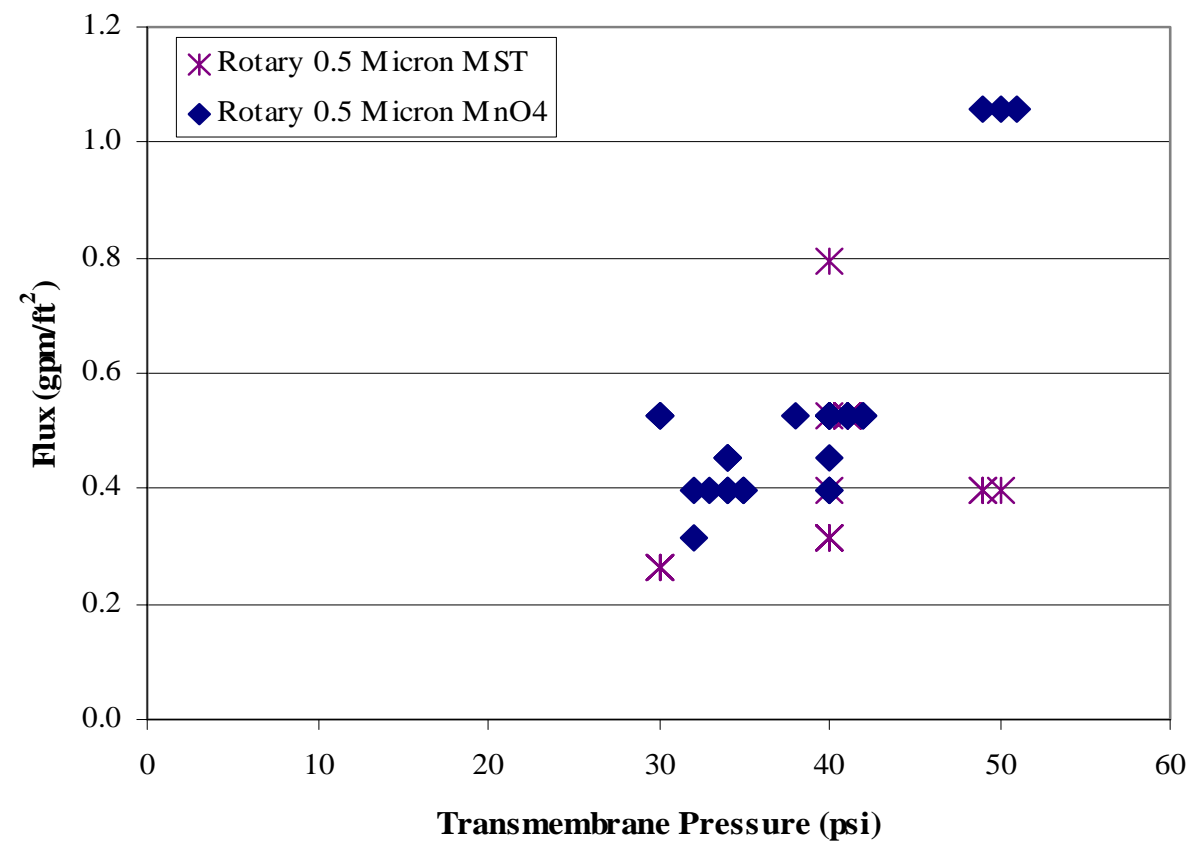

Figure 22. Rotary 0.5-Micron Filter Using Actual Waste at $4.5 \mathrm{wt} \% \mathrm{MST}$ and $11.7 \mathrm{wt} \% \mathrm{MnO}_{4}$

Figure 23 compares the data using MST for the 0.5-micron rotary filter to that for the 0.5-micron Mott cross-flow filter. Filtration rates proved significantly higher for the rotary filter. Filtration rates increased by a factor of 6 to 10 throughout the testing using the 0.5 -micron rotary filter with the stainless-steel permeate carrier. 
WSRC-TR-2003-00030, Rev. 0

Page 28 of 33

February 2003

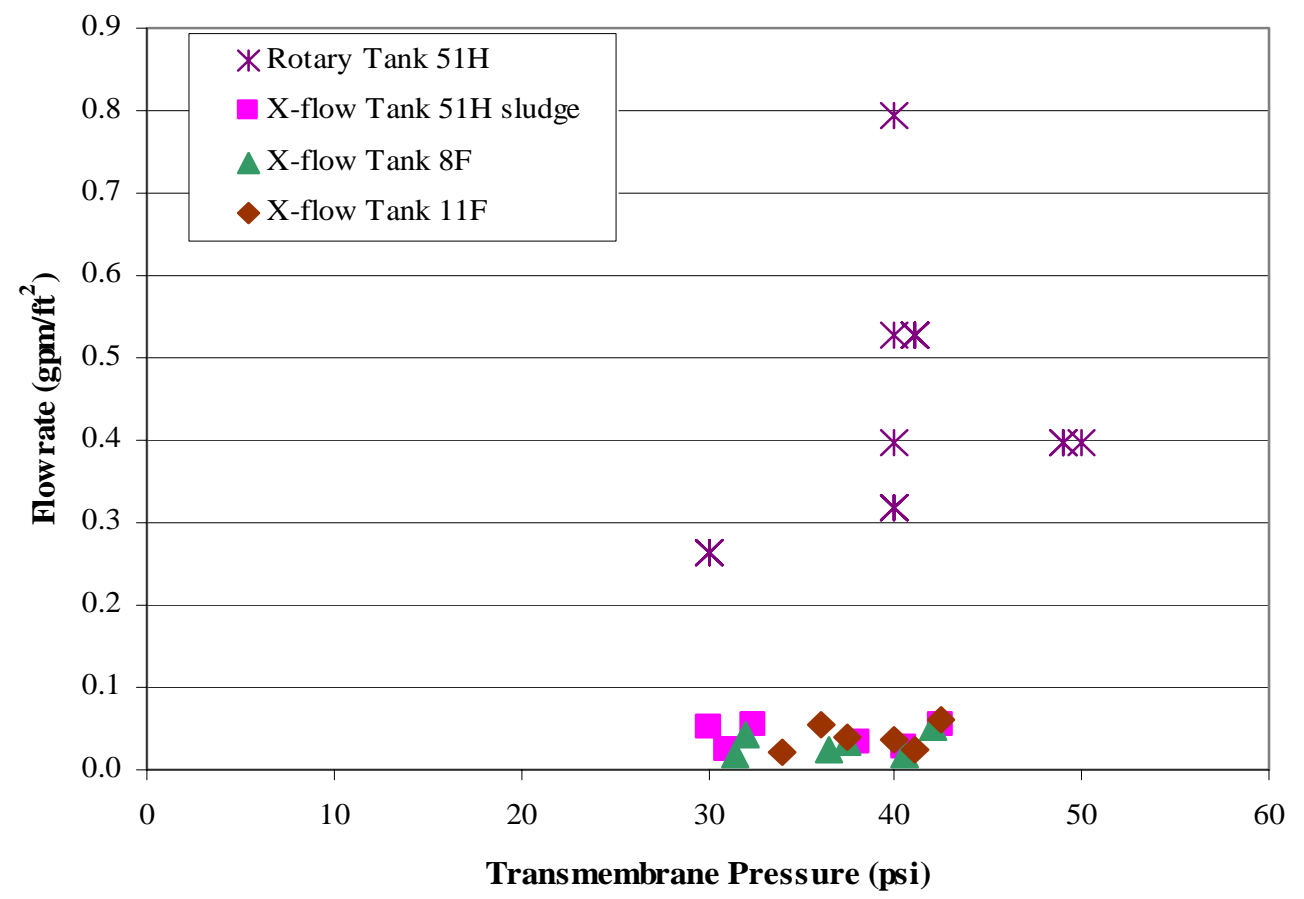

Figure 23. 0.5-Micron Rotary Filter and 0.5-Micron Cross-Flow Filter with 4.5 wt \% Insoluble Solids Using Actual Waste and MST

Figure 24 shows the 0.5 -micron rotary filter compared to the cross-flow filter with manganese oxide slurry at greater solids loadings. As with the MST, the rotary filter gave 3 to 10 fold increase in filtration flux.

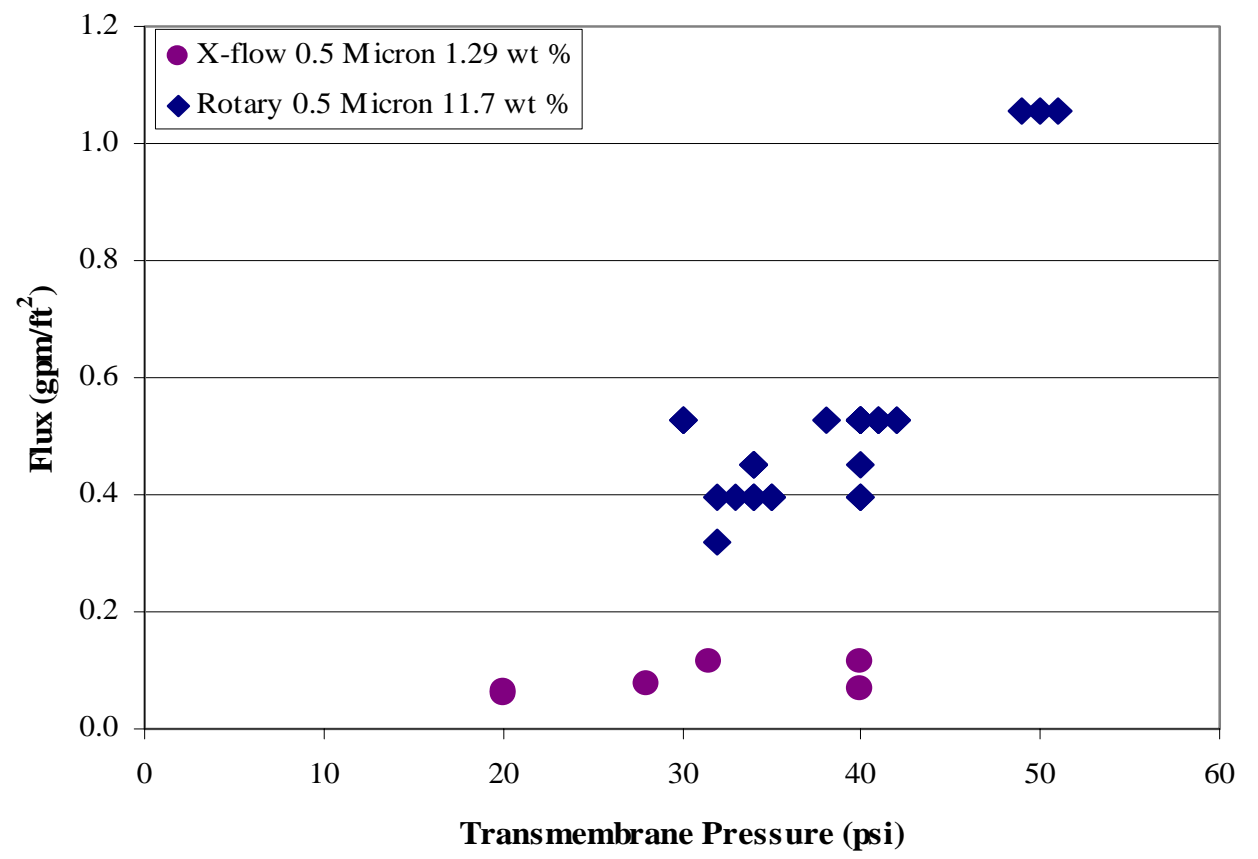

Figure 24. 0.5-Micron Rotary Filter with 11.7 wt \% Insoluble Solids and 0.5-Micron Cross-Flow Filter with 1.29 wt \% Insoluble Solids Using Actual Waste and $\mathrm{MnO}_{4}$ 
After completing these experiments, we prepared the slurries for disposal by filtering as much supernate as possible to reduce waste volume. We used the 0.5 -micron disk in the rotary filter. In contrast to the earlier experiments, which operated under total recycle of the filtrate, we operated the equipment in a feed concentration mode, separating the filtrate from the concentrate. We measured filtration rates by the rate of volume depletion for the feed tank. We filtered approximately 1 liter of supernate and recorded the filtration rate based on volume of the concentrated solution. We used this approach for both the MST and permanganate slurries starting with the most concentrated material. For the MST slurry, we removed approximately 8 liters of filtrate. We stopped filtering the permanganate slurry when the pump no longer functioned due to lack of feed. Tables 9 and 10 show the data for the MST-and permanganate-treated slurries, respectively. In both cases, the filtration rate remained well above the design target for the Salt Waste Processing Facility throughout the concentration range studied. This data suggests the possibility of concentrating the solids heel to a greater extent $(>5 \mathrm{wt} \%)$ than current plans, thereby reducing the required frequency of washing the final concentrated liquid and increasing the overall throughput of the facility.

Table 9. Filtration Rates for MST at Increasing Feed Concentrations

\begin{tabular}{|c|c|c|}
\hline $\begin{array}{c}\text { Approximate Solids } \\
\text { Concentration } \\
\text { (g/L) }\end{array}$ & $\begin{array}{c}\text { Transmembrane } \\
\text { Pressure } \\
\text { (psi) }\end{array}$ & $\begin{array}{c}\text { Flux } \\
\left(\mathbf{g p m} / \mathbf{f t}^{\mathbf{2}}\right)\end{array}$ \\
\hline 69 & 38 & 0.26 \\
\hline 77 & 37 & 0.26 \\
\hline 86 & 37 & 0.26 \\
\hline 98 & 36 & 0.26 \\
\hline 115 & 37 & 0.26 \\
\hline 138 & 36 & 0.26 \\
\hline 173 & 38 & 0.32 \\
\hline
\end{tabular}

Table 10. Filtration Rates for Permanganate at Increasing Feed Concentrations

\begin{tabular}{|c|c|c|}
\hline $\begin{array}{c}\text { Approximate Solids } \\
\text { Concentration } \\
\text { (g/L) }\end{array}$ & $\begin{array}{c}\text { Transmembrane } \\
\text { Pressure } \\
\text { (psi) }\end{array}$ & $\begin{array}{c}\text { Flux } \\
\left(\mathbf{g p m} / \mathbf{f t}^{\mathbf{2}}\right)\end{array}$ \\
\hline 169 & 26 & 0.40 \\
\hline 189 & 25 & 0.32 \\
\hline 219 & 25.5 & 0.32 \\
\hline 259 & 26 & 0.32 \\
\hline
\end{tabular}

\subsection{Conclusions}

In general, the rotary microfilter manufactured by SpinTek provided filtrate flows above those of the conventional cross-flow filter using the same filter media. However, inconsistencies in the filtrate rates occurred in early portions of the testing, which we attribute to a design limitation of the filter disks. We revised the design with a change of material and all subsequent data met or exceeded expectations of filtration flux rates.

The testing performed in this task agreed with previous testing using simulants, with results showing 2 to 6 times increase in filtration flux using the 0.1-micron SpinTek rotary filter over the 0.5-micron cross-flow filter under similar conditions. These results agree with previous testing using simulants performed by the vendor.

Results for actual waste testing with MST and a 0.1-micron rotary filter showed a modest improvement of filter flux, ranging from a 0 to $100 \%$ improvement compared to prior tests using a 0.5 -micron cross-flow filter, with filtration rates ranging from 0.04 to $0.13 \mathrm{gpm} / \mathrm{ft}^{2}$. Filtration rates using permanganate showed little improvement in filtration rate using the rotary 0.1 -micron filter as compared to the 0.5 -micron crossflow filter. Filtration rates for the rotary filter ranged from 0.006 to $0.08 \mathrm{gpm} / \mathrm{ft}^{2}$. Analysis of the data as a function of time and post-test investigation suggest the 0.1 -micron filter disk, specifically the permeate 
carrier, deteriorated over the course of the experiments. We believe the flow path created by the polypropylene permeate carrier became successively constricted during the experiments, due to a combination of radiation effects and heat, causing inconsistencies in performance. Hence, these experiments resulted in a low bias for the performance of the equipment. We corrected this design flaw for the 0.5 -micron filter testing by replacing the polypropylene mesh with an all-stainless-steel mesh.

A significantly higher flux rate occurred for the 0.5-micron rotary filter versus the 0.1-micron rotary filter. Testing with the 0.5 -micron rotary filter gave filtration rates ranging from 0.26 to $0.76 \mathrm{gpm} / \mathrm{ft}^{2}$ for MST and 0.32 to $1.06 \mathrm{gpm} / \mathrm{ft}^{2}$ for permanganate. This improvement is an increase in flux of 6 to 10 times over the 0.5 -micron cross-flow filter for either MST or sodium permanganate.

Treatment with MST followed by rotary filtration produced a strontium DF of 3 to 5, but the samples did not meet the design specification value. We identified several potential contributors for the failure to obtain the strontium DF. Among these are that the feed was not equilibrated, filter breakthrough, MST batch variability, MST particle attrition and sludge attrition. We believe the most likely contributor to the strontium results involved the attrition of the sludge. This attrition would release additional strontium originally bound in the sludge. The slow kinetics of the MST would require additional time to absorb the freed strontium.

For the treatment with MST, we measured a DF of 3 to 6 for plutonium even with the initial concentration less than the design specification. The DF for uranium equaled 0.7 to 2.0. For the neptunium we measured a DF of 4 to 8 , even though it initially met the design specification.

For permanganate, treatment produced a DF for strontium greater than 40 and a concentration after treatment in all samples of less than the design specification value. The plutonium was initially less than the design specification, but we measured a DF of 2 to 4 . The DF for uranium equaled 1.2 to 1.4. We measured a DF of 4 to 7 for the neptunium concentration. The neptunium concentration initially met the design specification.

We did not encounter any notable mechanical problems while testing the feed solutions incorporating MST using either simulated or actual waste. We experienced pumping problems with the actual waste testing incorporating the permanganate solution. These problems included a plugged pump suction line during higher solids testing. We observed one slug of solids passing through the piping system that eventually cleared.

We note that the Actinide Removal Process (Building 512-S) has a rate of throughput approximately $1 / 6^{\text {th }}$ the design value for the Salt Waste Processing Facility. These data suggest that the rotary filter may offer the potential to completely de-bottleneck ARP relative to filtration if we can accommodate the equipment within the same footprint.

\subsection{Path Forward/Recommendations}

Based on the results of this testing program, we recommend additional testing and design effort for the rotary microfilter. The composite data to date indicate marked improvements - as much as 10 times available in filtration rates, simpler cleaning, and the potential to process more concentrated slurries. Personnel should conduct a systems assessment evaluating these gains versus the offsetting challenges of the rotating equipment design. However, present data suggests the equipment merits consideration both in the design of the Salt Waste Processing Facility and perhaps more immediately in the Actinide Removal Process (within Building 512-S).

We recommend the program team also extend the assessment to include competing designs for the rotary microfilter. For instance, the review should also consider the analogous equipment developed by Russian firms and marketed by the ASPECT USA consortium. While very similar in design concept to the SpinTek equipment, that configuration includes an antechamber for precipitation or sorbent chemistry. Also, the 
WSRC-TR-2003-00030, Rev. 0

Page 31 of 33

February 2003

Russian design uses filter disks consisting entirely of stainless-steel parts, omitting the plastics used in the current testing.

We recommend repeating a limited portion of the testing for the MST slurry using a 0.1-micron pore-size of the modified design. Alternatively, the program may elect to defer this testing until after completely redesigning the filter disk.

We recommend additional studies related to the potential for sheared sludge to release strontium (and actinides) after treatment with MST. Should later testing confirm this phenomenon, design modifications may prove necessary to mitigate the processing risk.

\subsection{Quality Assurance}

This study fulfills the activity defined in "Task Technical and Quality Assurance Plan for the Filtration Test Using the SpinTek Rotary Microfilter”, WSRC-RP-2002-00201, Rev. 0, March 25, 2002. All data and notes from testing are recorded in WSRC-NB-2001-00169 and subsequent notebooks.

\subsection{Acknowledgements}

The authors thank Tim Allen and Monica Jenkins for their diligence and dedication in performing all testing on the SpinTek rotary filter. We also extend our appreciation to Gary Hall for the development of all the tools required to maintain the filter system and for his assistance in developing the operational techniques adopted and used throughout testing. We thank Ron Blessing for his assistance in modifying the system, making it operational in the shielded cells environment. We thank David Martinez and Cassie Robinson of the SRTC Robotics group for their assistance in making the electronics operational. Henry Bolton prepared all chemical reagents necessary for testing. Elizabeth Coleman provided support during neutralization and cleanup as well as logistical support. Debbie Sanders helped locate spare parts and provided logistical support. We also extend our appreciation to Jason Gilmour and Bill Greene of SpinTek for their support and willingness to work with us. We thank the Analytical Development Section of SRTC for providing sample analysis and Curt Sexton of the SRTC Glass Shop for providing the sight glass. Finally, we thank Terry Todd and Eric Peterson of the Idaho National Environmental Engineering Laboratory for their consultations on what to look for in the vendor design and sharing their lessons learned. 


\subsection{References}

1 H. H. Saito, M. R. Poirier, S. W. Rosencrance, J. L. Siler, "Improving Filtration Rates of MonoSodium Titanate (MST)-Treated Sludge Slurry with Chemical Additives,” WSRC-TR-99-00343, September 15, 1999.

2 H. H. Saito, M. R. Poirier, J. L. Siler, "Effect of Sludge Solids to Mono-Sodium Titanate (MST) Ratio on MST-Treated Sludge Slurry Cross-Flow Filtration Rates," WSRC-TR-99-00342, September 15, 1999.

3 Ralph Haggard, Travis Deal, Carol Stork, and Vince Van Brunt, "Final Report on the Crossflow Filter Testing for the Salt Disposition Alternative," USC-FRED-PSP-RPT-09-0-010, Rev. 0, December 4, 1998.

M. R. Poirier, “FY2000 FRED Test Report,”WSRC-TR-2001-00035, Rev. 0, January 11, 2001 and included report "Final Report on the Crossflow Filter Optimization with 5.6 M Sodium Salt Solution” (V. Van Brunt, C. Stork, T. Deal, and R. Haggard, USC-FRED-PSP-RPT-09-0-015, December 20, 2000).

5 M. J. Barnes, D. T. Hobbs, M. C. Duff, S. D. Fink, "Permanganate Reduction of Savannah River Site Actual Waste Samples for Strontium and Actinides Removal," WSRC-TR-2002-00048, February 21, 2002.

M. C. Duff, D. T. Hobbs, S. D. Fink, "Permanganate Treatment Optimization Studies For Strontium and Actinide Removal from High-Level Waste Simulants," WSRC-TR-2002-00027 Rev 0., January 14, 2002.

M. R. Poirier, F. F. Fondeur, T. L. Fellinger, S. D. Fink, "Cross-Flow Filtration Demonstration for Slurries Containing High-Level Waste Sludge and Monosodium Titanate,” WSRC-TR-200100212, April 11, 2001.

M. R. Poirier, J. L. Siler, and S. D. Fink, "Filtration of Actual Savannah River Waste Treated with Permanganate or Monosodium Titanate,” WSRC-TR-2002-00134, March 14, 2002.

M. R. Poirier, "Filtration Systems, Inc., Report for SRS SpinTek Rotary Microfilter Testing," WSRC-TR-2001-00214, Rev. 1, May 4, 2001.

S. D. Fink, D. D. Walker, and M. C. Thompson, "WSRC Salt Processing," TTP SR01WT21, September 18, 2001.

SpinTek High Shear Membrane Filtration, Speedy Test Unit, Model ST-II-1 Operations Manual.

W. A. Greene, P. A. Kirk, R. Hayes, and J. Riley, "Centrifugal Membrane Filtration Final Report," FETC Test Report submitted under contract DE-AC21-96MC33136, August 4, 1999.

"Procedure for the Operation of the SpinTek Rotary Microfilter," IWT-OP-142 Rev. 0.

M. A. Norato, S. D. Fink, F. F. Fondeur, G. F. Kessinger, R. A. Pierce, and D. D. Walker, "Demonstration of Caustic-Side Solvent Extraction with Optimized Solvent in the 2-cm Centrifugal Contactor Apparatus using Dissolved Salt Cake from Tank 37H," WSRC-TR-200200307. 
16 T. A. Todd, N. R. Mann, T. J. Tranter, F. Sebesta, J. John and A. Motl, "Cesium Sorption from Concentrated Acidic Tank Wastes Using Ammonium Molybdophosphate-Polyacrylonitrile Composite Sorbents," Journal of Radioanalytical and Nuclear Chemistry, 254(1), 47-52, (2002).

17 S. D. Fink, D. T. Hobbs, and T. B. Peters, "Demonstration of MST Efficacy on Removal of Actinides and Strontium in 'Bounding Alpha' Waste," WSRC-TR-2002-00555, December 17, 2002.

18 D. T. Hobbs, "Recommended Decontamination Factors for Use in Flowsheet Modeling of the Manganese Oxide Treatment Process for Strontium and Actinide Removal," WSRC-TR-200200379, August 20, 2002.

19 S. D. Fink and M.R. Poirier, "Recommendation for Using Smaller (0.1 $\mu$ ) Pore-Size Media for Filtration in Salt Waste Processing Project," WSRC-TR-2002-00341.

20 R. A. Dimenna, H. H. Elder, J. R. Fowler, R. C. Fowler, M. V. Gregory, T. Hang, R. A. Jacobs, P. K. Paul, J. A. Pike, P. L. Rutland, F. G. Smith, S. G. Subosits, G. A. Taylor, S. G. Campbell, and F. A. Washburn, "Bases, Assumptions, and Results of the Flowsheet Calculations for the Decision Phase Salt Disposition Alternatives," WSRC-RP-99-00006, Revision 3, May 24, 2001.

D. T. Hobbs, ”SR Actinide Removal," WSRC-NB-2001-00011, pp. 104-115.

N. L. Dietz, J. A. Fortner, Z. Dai, J. P. Bradley, M. C. Duff, D. T. Hobbs, and S. D. Fink, "Transmission Electron Microscopy Analysis of Strontium and Actinide-Bearing Monosodium Titanate and Permanganate Treatment Solid,” WSRC-TR-2002-00363, August 26, 2002.

M. R. Poirier, D. T. Herman, S. D. Fink, R. Haggard, T. Deal, C. Stork, V. Van Brunt, "PilotScale Testing of a SpinTek Rotary Microfilter with SRS Simulated High Level Waste," WSRCTR-2003-00071, February 3, 2003. 